\title{
Linking Framework Geology and Nearshore Morphology: Correlation of Paleo-Channels with Shore-Oblique Sandbars and Gravel Outcrops
}

\author{
A. Grace Browder \\ College of William and Mary - Virginia Institute of Marine Science
}

Follow this and additional works at: https://scholarworks.wm.edu/etd

Part of the Geomorphology Commons, and the Oceanography Commons

\section{Recommended Citation}

Browder, A. Grace, "Linking Framework Geology and Nearshore Morphology: Correlation of PaleoChannels with Shore-Oblique Sandbars and Gravel Outcrops" (2005). Dissertations, Theses, and Masters Projects. Paper 1539617839.

https://dx.doi.org/doi:10.25773/v5-yt9c-dy21

This Thesis is brought to you for free and open access by the Theses, Dissertations, \& Master Projects at W\&M ScholarWorks. It has been accepted for inclusion in Dissertations, Theses, and Masters Projects by an authorized administrator of W\&M ScholarWorks. For more information, please contact scholarworks@wm.edu. 
LINKING FRAMEWORK GEOLOGY AND NEARSHORE MORPHOLOGY: CORRELATION OF PALEO-CHANNELS WITH SHORE-OBLIQUE SANDBARS AND GRAVEL OUTCROPS

\author{
A Thesis \\ Presented to \\ The Faculty of the School of Marine Science \\ The College of William and Mary in Virginia
}

In Partial Fulfillment

Of the Requirements for the Degree of

Master of Science

by

A. Grace Browder

2005 
APPROVAL SHEET

This thesis is submitted in partial fulfillment of

the requirements for the degree of

Master of Science

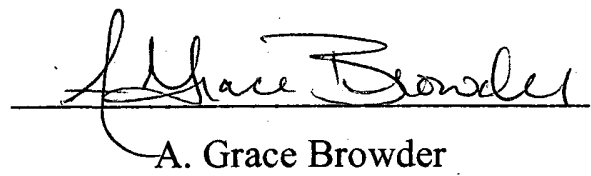

Approved, July 2005

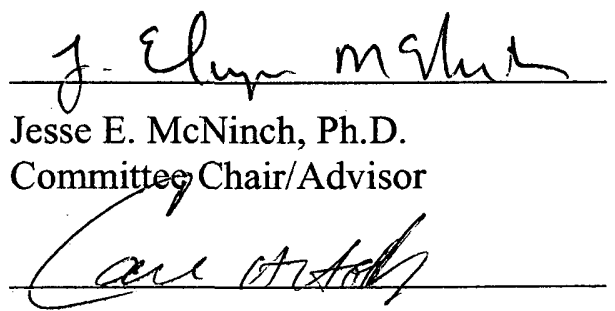

Carl H. Hobbs, III, Ph.D.

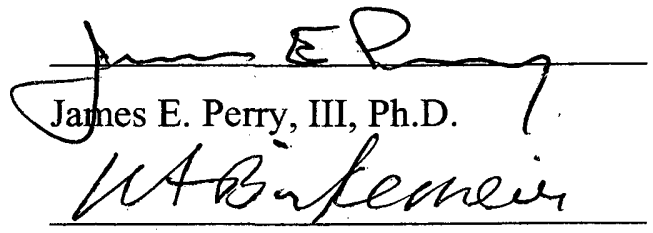

William A. Birkemeier 
TABLE OF CONTENTS

Page

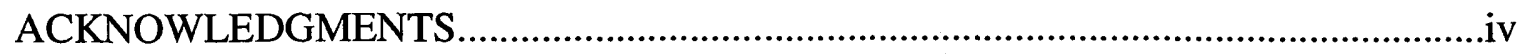

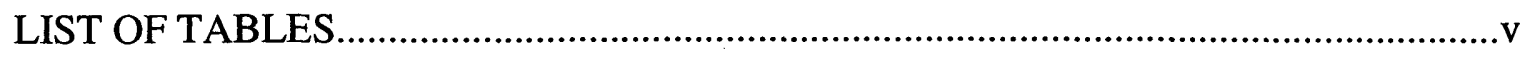

LIST OF FIGURES

ABSTRACT .......................................................................................................

INTRODUCTION

Framework geology and shoreline behavior..........................................................5

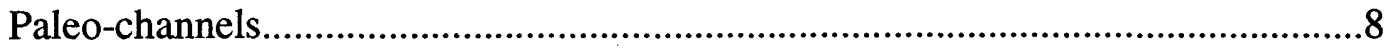

Shore-oblique sandbars and gravel outcrops.........................................................

STUDY AREA

Physical setting.............................................................................................12

Geologic setting ............................................................................................13

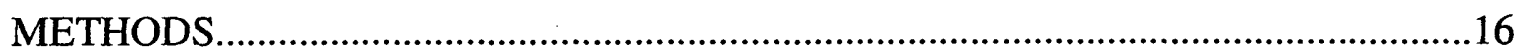

Data collection and processing.........................................................................16

Statistical analysis...............................................................................................17

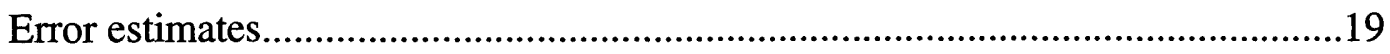

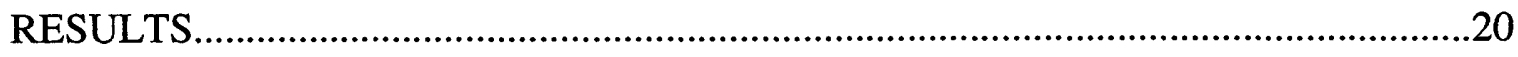

Observed shore-oblique bars, gravel outcrops and paleo-channels........................20

Correlation of buried channels and nearshore outcrops/shore-oblique bars...........21

Spatial correlation using mapped bathymetry and channel locations......................21

Differences in sub-bottom cross-sections...................................................21

Statistical correlation...................................................................................22

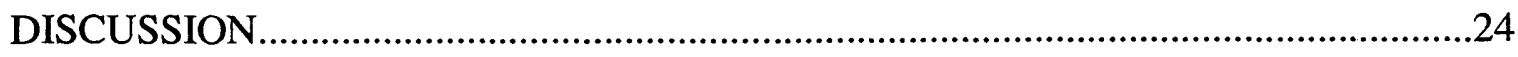

Correlation of shore-oblique bars/outcrops with paleo-channels..........................24

Prospective field and management applications.......................................................28

Prospective mechanisms...................................................................................29

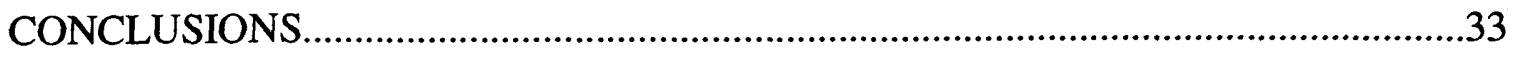

VITA 


\section{ACKNOWLEDGMENTS}

Thanks to my advisor Dr. Jesse McNinch for taking a chance on an aspiring coastal geologist disguised as a French/Bio major. I appreciate his limitless kindness and patience and am repeatedly inspired by his never-waning enthusiasm for science. My committee offered continuous and varied support: Thank you to Woody Hobbs for being such a great and tireless resource for geology and grammar. Thanks to Jim Perry for not letting us all lose sight of how my research relates to plants and dune ecology. And thanks to Bill Birkemeier for providing extremely helpful feedback and a beautiful place to study coastal geology (USACE FRF, Duck, NC)!

Special thanks to my lab, The Pelican group: Papa Pelican (Jesse McNinch), Party Pelican (Jennifer Miselis), Prozac Pelican (Heidi Romine) and Pensive Pelican (Jun Yong Park). Jen has been an incredible mentor in the ways of coastal geology and graduate school, and without Heidi's tutelage, I absolutely could not have made it through my semester of teaching undergraduate geology.

None of this work (or the work from which it stems) could have been accomplished without the patience and dedication of Captain Charles Machen of the R/V Pelican (formerly of the R/V Langley), VIMS, and Ray Townsend and colleagues of the U.S. Army Corps of Engineers Field Research Facility at Duck, NC. Funding was provided by the Minerals Management Service (Cooperative Agreement 1435-01-98-CA-303934), US Geological Survey (Cooperative Agreement 02ERAG0034) and the US Army Research Office (Grant \#DAAD19-02-1-0307).

Finally, I'd like to thank my family for always supporting my educational endeavors and Kurtis Gray for providing great company, endless encouragement, copious laughter and, when things get especially desperate, oreo ice cream. 


\section{LIST OF TABLES}

Table 1. Summary of average characteristics for each bar field...

Table 2. $2 \times 2$ contingency table for chi square analysis showing the frequency of occurrence of bars and channels. Presence / absence determinations for bars and channels were made every $10 \mathrm{~m}$ in the alongshore direction for each study site.

Table 3. Correlation coefficients resulting from cross-correlation analyses between paleo-channels and shore-oblique sandbar/gravel outcrop regions. Analyses were run using channel depths determined in three different ways:

referenced to the seafloor, referenced to the top of the channel cross-section and finally, a depth measurement which subtracts the amount of burial (DBSF) from the channel depth 


\section{LIST OF FIGURES}

Figure

1. A sequence of nearshore bathymetry collected at the Kitty Hawk, North Carolina site that encompasses a region characterized by a smooth, convex shoreface adjacent to large, shore-oblique sandbars and troughs. (A) Three-dimensional block diagram of depths measured after Hurricane Isabel in November 2003. (B) November color bathymetry with March 2003 bathymetry (post-northeaster storm) overlain as white contours. (C) May 2002 bathymetry (fair weather), shown as white contours, with the November 2003 colored bathymetry. The large-scale morphology and position of these shore-oblique features remained similar after each fair-weather and post-storm survey. From McNinch, 2004

2. A chirp cross-section of a channel mapped in the nearshore of Kitty Hawk, NC, perhaps the main thalweg of the paleo-Roanoke-Albemarle fluvial system. Despite vertical exaggeration, it is evident that the upper layers of channel fill are more gently sloping, suggesting the presence of estuarine muds and clays resulting from transgressional backfilling.

3. Panel A: Schematic of relict tidal inlet cross-section following Moslow and Heron (1978). Panel B: Chirp seismic cross-section from the nearshore region of Sandbridge, VA.

4. Location of study sites in southeastern Virginia and northeastern North Carolina..41

5. Bathymetry from Sandbridge, VA site overlain with navigation lines (solid red lines), locations of channel cross-sections shown in Figure 14 (dotted yellow lines), locations of gravel outcrops shown in Figure 12A (green dots), and locations of sub-bottom cross-sections shown in Figure 20 (dotted blue lines)

6. Bathymetry from Kitty Hawk, NC site overlain with navigation lines (solid red lines), locations of channel cross-sections shown in Figure 15 (dotted yellow lines), locations of gravel outcrops shown in Figure 12B (green dots), and locations of subbottom cross-sections shown in Figure 21 (dotted blue lines).

7. Bathymetry from Nags Head, NC site overlain with navigations lines (solid red lines), locations of channel cross-sections shown in Figure 16 (dotted yellow lines), locations of gravel outcrops shown in Figure 13 (green dots), and locations of subbottom cross-sections shown in Figure 22 (dotted blue lines)

8. Outline of paleo-Roanoke-Albemarle fluvial system mapped on the continental shelf off of northeastern North Carolina. From Boss et al., 2002 
9. Schematic showing the methodology of determining and quantifying bar and channel parameters. Channel and bar endpoints were traced to an arbitrary channel and bar baseline, respectively. Every 10 meters along the channel baseline, a bar metric and channel depth were compiled in a spreadsheet. Bar metrics were based on length $(\ell)$ and width $(\boldsymbol{\omega})$ of each bar. (See Methods section for more complete description).

10. Chirp seismic image showing digitized channel and method of measuring channel parameters. $\mathrm{DBSF}=$ Depth below seafloor.

11. 3-D images of a) Sandbridge, VA bar field, b) Kitty Hawk, NC bar field and c) Nags Head, NC bar field. Ellipses highlight bar region. (Images are highly vertically exaggerated.).

12. Representative side-scan images from A) a Sandbridge, VA gravel outcrop and B) a Kitty Hawk, NC gravel outcrop.

13. Representative side-scan image from Nags Head, NC. Yellow indicates higher backscatter, and thus coarser sediment.

14. Representative relict channel cross-sections from the Sandbridge, VA sub-bottom record. Top panel shows data collected along the $5 \mathrm{~m}$ isobath and bottom panel shows the same channel captured at the $7 \mathrm{~m}$ isobath.

15. Relict channel cross-section from the Kitty Hawk, NC sub-bottom record collected in $15 \mathrm{~m}$ of water.

16. Representative relict channel cross-sections from the Nags Head, NC sub-bottom record. Top panel shows data collected along the $12 \mathrm{~m}$ isobath and bottom panel shows the same area of chaotic reflectors recorded at the $15 \mathrm{~m}$ isobath.

17. Sandbridge, VA bathymetry data overlain with gravel outcrop locations (white squares) and channel boundaries (dotted lines). Wider channels (presumed to be fluvial) are colored yellow, while narrow (presumably tidal inlet) channels are colored red

18. Kitty Hawk, NC bathymetry data overlain with gravel outcrop locations (white squares) and channel boundaries (dotted lines).

19. Nags Head, NC bathymetry data overlain with gravel outcrop locations (white squares) and channel boundaries (dotted lines). Wider channels (presumed to be fluvial) are colored yellow, while narrow (presumably tidal inlet) channels are colored red 
20. Sandbridge sub-bottom cross-sections. A-A' lies outside the bar area and exhibits gently sloping reflectors. B-B' falls within the bar area and shows chaotic and truncated reflectors, evidence of channel meandering and downcutting. Crosssection locations are shown in Figure 5.

21. Kitty Hawk sub-bottom cross-sections. As in Sandbridge (Figure 10), only those cross-sections underlying the bar area show evidence of buried paleo-channels. Cross-section location is shown in Figure 6.

22. Nags Head sub-bottom cross-sections. Neither line falls near the shore-oblique bar/gravel outcrop region and neither line reveals relict channels. Cross-section locations are shown in Figure 7

23. Graph of paleo-channel depths and bar metrics plotted against location (northing, UTM) every 10 meters in the alongshore direction.

24. Cross-correlation analysis results for the Sandbridge, VA site. Green line represents a random comparison, blue line represents a perfect correlation and the pink dotted line represents the actual results of the analysis in question. $\mathrm{Cc}=$ correlation coefficient.

25. Cross-correlation analysis results for the Kitty Hawk, NC site. Green line represents a random comparison, blue line represents a perfect correlation and the pink dotted line represents the actual results of the analysis in question. $\mathrm{Cc}=$ correlation coefficient.

26. Cross-correlation analysis results for the Nags Head, NC site. Green line represents a random comparison, blue line represents a perfect correlation and the pink dotted line represents the actual results of the analysis in question. $\mathrm{Cc}=$ correlation coefficient.

27. Cross-correlation analysis results for all sites (analyzed together). Green line represents a random comparison, blue line represents a perfect correlation and the pink dotted line represents the actual results of the analysis in question. $\mathrm{Cc}=$ correlation coefficient.

28. Locations of relict channels in Onslow Bay identifiable in the seismic record at the $10 \mathrm{~m}$ isobath (from Hine and Snyder, 1985) and superposition of 1998 shoreline change rates (from NC Division of Coastal Management). Shaded areas show where elevated erosion rates shown on the graph correspond with the shoreline....65 


\begin{abstract}
This work describes a newly discovered spatial correlation between paleochannels and nearshore morphology along the barrier islands of the U.S. mid-Atlantic coast of the northern Outer Banks of North Carolina and southern Virginia. These nearshore morphological features include regions of shore-oblique sandbars and coincident gravel outcrops that previously have been linked to shoreline hotspots. The importance of these new findings has direct bearing on both nearshore morphodynamics and shoreline management. Paleo-channels were identified in the chirp seismic record and compared to locations of shore-oblique sandbars gleaned from bathymetric data and corroborated by gravel outcrops depicted in the side-scan record. Both graphical correlation and statistical cross-correlation analyses revealed a significant spatial relationship between these features, with higher statistical correlation for channels $>500$ $\mathrm{m}$ wide. Seismic records also indicate that the gravel outcrops seen on the updrift flanks of the shore-oblique bars are surface expressions of the underlying geology. We hypothesize that these outcrops are composed of relict channel fill sediments that interact with the hydrodynamic regime to produce sorted bedforms. The bathymetric anomalies then serve to alter incident wave energy and affect shoreline behavior. The spatial and temporal stability of these features over several years and through a variety of wave conditions suggests some degree of underlying geologic control. While the mechanisms responsible for this relationship remain speculative, these results may bridge the gap between studies focusing on framework geology and its influence on shoreline change and those that investigate bar morphodynamics and the initiation of sorted bedforms.
\end{abstract}


LINKING FRAMEWORK GEOLOGY AND NEARSHORE MORPHOLOGY:

CORRELATION OF PALEO-CHANNELS WITH SHORE-OBLIQUE SANDBARS AND GRAVEL OUTCROPS 


\section{INTRODUCTION}

This thesis addresses the strong spatial correlation between paleo-channels buried beneath the modern shoreface and morphologic anomalies, shore-oblique bars and outcropping gravel patches, seen in the surf zone and nearshore. This correlation holds major implications for shoreline management, since the aforementioned anomalies have been linked to areas of excessive shoreline erosion (McNinch, 2004). In addition, the correlation provides further evidence supporting the growing consensus of a link between underlying geology and shoreline behavior. Throughout this study, the terms underlying geology, framework geology and antecedent geology are used interchangeably to refer to the sediments which underlie the modern deposits, to a depth of $\sim 10 \mathrm{~m}$. One of the more exciting aspects of this research is that it bridges the gap between two prominent but separate current research endeavors: influence of framework geology on shoreline behavior (Demarest and Leatherman, 1985; Gayes, 1998; Honeycutt and Krantz, 2003; Kraft et al., 1987; McNinch, 2004; Pilkey et al., 1993; Riggs et al., 1995; Schupp et al., 2002; Schwab et al., 2000) and nearshore sorted bedforms (Green et al., 2004; Gutierrez et al., 2005; Murray and Thieler, 2004; Trembanis et al., 2004). We will present the varied natures of the channels seen in the seismic record and highlight what appear to be the most important parameters in determining potential influence on seabed morphological characteristics. We will also propose several hypotheses that address how a buried relict feature might have an effect on the modern nearshore environment. 
A reconnaissance survey undertaken in the summer of 2002 brought to light an apparent spatial relationship between shore-oblique sandbars in the nearshore and shoreline erosion (McNinch, 2004). The purpose of the survey was to investigate the previously unmapped framework geology of the nearshore (McNinch et al., 2002). This study utilized chirp seismic and interferometric swath bathymetry to provide a threedimensional view along $56 \mathrm{~km}$ of the nearshore of southeastern Virginia and the northern Outer Banks of North Carolina. This survey further revealed a vertical and horizontal heterogeneity in sediment size and composition across the study area. The layer of modern sand was relatively thin (from 0 to $1.5 \mathrm{~m}$ thick) and was concentrated in several locations in clusters of shore-oblique sandbars. In all cases, these sandbars were flanked by gravel patches that were shown to be surface expressions of the underlying substrate. Repeat surveys in March 2003 and November 2003 (only six weeks after Hurricane Isabel) of one of the largest of these clusters showed remarkable spatial stability (Figure 1). More interesting still is the apparent spatial alignment between these larger shore oblique bar/outcrop regions and the locations of long-term erosional hotspots (Schupp, 2005).

Erosional hotspots are problematic regions of coastline that display great variability and resist classification and prediction (Fenster and Dolan, 1993). These areas exhibit anomalously high erosion or accretion, as well as spatial and temporal variability (Benton et al., 1997; Hobbs et al., 1999; List and Farris, 1999). Shoreline hotspots challenge our knowledge and understanding of alongshore transport and cross-shore sediment exchange and for this reason have been the subject of much study in recent years (McNinch, 2004). Specifically, they raise the question of why there is localized 
variation in shoreline behavior where longshore transport of sediment is such a dominant process. While some hotspots may be explained by their proximity to coastal engineering projects (Dean et al., 1999; Kraus and Galgano, 2001) and inlets (Fenster and Dolan, 1996), it has become evident that in order to explain many of these features, shoreline prediction models need to look beyond the principle variables of waves and bathymetry to other possible controlling factors.

Traditionally, beaches have been thought to respond to physical forcings as described by Bruun (1954). His equation, $\mathrm{h}=\mathrm{Ay}^{2 / 3}$ (where $\mathrm{h}=$ water depth, $\mathrm{y}=$ distance offshore and A is a constant that parameterizes grain size), predicts that there is some common profile that all beaches will reach if the principle physical forcings (waves, grain size, sea level) remain constant. Characteristics of such an equilibrated beach were described by Dean (1991) as a planar shoreface, a concave-upward profile, and slopes dictated by grain size and wave steepness. In 1962, Bruun brought the effect of rising sea level to bear on his earlier concept and presented a model that is now known as "Bruun's Rule" whereby the dimensions of the equilibrium profile remain unchanged, but simply shift landward and upward with transgression (Pilkey et al., 1993). The concept of a dynamic equilibrium profile is used in many coastal engineering models and according to Pilkey et al., assumes the following, (1993): 1) Sediment movement is influenced only by incident wave energy. 2) There exists a "depth of closure" beyond which there is no net exchange of sediment. 3) The shore-face consists of a thick wedge of sand that is not influenced by underlying geology. While the profile of equilibrium model is a good first approach and is applicable in a large majority of instances, there are exceptions to this rule. 
The findings of the 2002 reconnaissance study challenge the existing paradigm of a dynamic shoreface morphology that is two-dimensional in nature and strictly controlled by waves and mean grain size (McNinch, 2004). Specifically, they raise the questions of why shore-oblique sandbars persist through storms, why outcrops remain exposed and what dictates their location. This persistence is noteworthy given the high energy environment of the nearshore. The present study explores the possibility that the location of the shore-oblique bar and outcrop clusters are influenced by the framework geology of the nearshore. The notion that a buried feature could have any communication with the modern substrate is not immediately intuitive, but this study introduces some mechanisms that might explain this phenomenon.

\section{Framework geology and shoreline behavior}

There is a steadily growing body of literature exploring the effect that framework geology may have on beach and nearshore behavior (Belknap and Kraft, 1985; Demarest and Leatherman, 1985; Honeycutt and Krantz, 2003; McNinch, 2004; McNinch and Drake, 2001; Pilkey et al., 1993; Rice et al., 1998; Riggs et al., 1995). Some framework geology studies have looked at the implications of underlying and outcropping relict sediments on shoreline change (Honeycutt and Krantz, 2003; McNinch, 2004; Riggs et al., 1995; Schupp, 2005). Honeycutt and Krantz (2003) found that the character (lithology and degree of compaction) of underlying relict units in the nearshore of Bethany Beach, Delaware, was a controlling factor in the rate of shoreline erosion. In one cited example, an early Holocene unit slowed the rate of shoreline erosion by acting 
as a sediment source. In another, an erosion-resistant Pleistocene headland also slowed erosion rates, but as a result of greater compaction relative to nearby Holocene sediments. Riggs and others (1995) found that increased shoreline erosion occurred in areas of the northern Outer Banks where relict channels could be traced in the stratigraphic record. They attributed this to the characteristics of the type of fill. The most rapid shoreline recession was associated with sandy sediments (typical of relict inlet channels). Erosion of these sediments resulted in steeper shoreface profiles and the eventual supply of these materials (similar in composition to the modern sands) to adjacent beaches. Shorefaces underlain by estuarine sediments (typical of relict fluvial channels) eroded more slowly and produced profiles that were less steep than those underlain by predominantly sandy sediments. Once eroded, the fine-grained sediments were suspended and transported offshore. Riggs et al. (1995) did find coarser-grained material in the cores from relict fluvial channels, but did not consider these in the shoreline change question since they generally are buried beneath the estuarine sediments. The present study has identified gravel sediments cropping out near buried fluvial channels in the nearshore. These gravel outcrops are believed to play an important role in influencing overlying sediment behavior.

Other studies have focused on the contribution of relict sediments to the modern sediment budget, a concept known as shoreface bypassing (Swift, 1976). Demarest and Leatherman (1985) found relict sediments to be a significant source of sand for modern beaches along the Delmarva Peninsula. Schwab et al. (2000) traced an offshore source of relict sediment near Long Island, New York to a pre-Holocene subaerial headland that had been eroded during the Holocene transgression. The eroded sediment was reworked 
into shoreface-attached sand ridges that now appear to be significant contributors to the modern littoral system. In large part, these studies demonstrate that there is a connection between the framework geology and shoreline change but do not provide mechanisms to explain this connection. Honeycutt and Krantz (2003) presented three ways in which framework geology may influence shoreline-change rates: 1) the differential erosion of underlying sediments causes discontinuity in erosion rates, 2) shoreline retreat is slowed by relict topographic highs and hastened by relict topographic lows, and 3) relict sediments (if they are similar in size and composition to modern sediments) may supply local beaches. One important possibility they do not address is how the outcropping of relict sediments might affect the hydrodynamic regime and nearshore bedforms.

Cox (1995) found that a consolidated Pleistocene submarine headland near Rodanthe, NC dramatically influenced the distribution of nearshore wave energy, thus acting as a major control on shoreline behavior. Bender and Dean (2003) used both field studies and modeling efforts to examine how changes in offshore bathymetry modified local wave fields and shoreline. These and other modeling efforts have consistently shown that bathymetric irregularities on the shelf, which are often a product of antecedent geology, are a major influence on incident waves (Maa and Hobbs, 1998; O'Reilly and Guza, 1993) and, thus, shoreline behavior.

There is also a growing body of work exploring how bedform morphology can be influenced by different sediment types exposed on the seafloor. Trembanis et al. (2004) examined bottom boundary layers over a smooth sandy bed and a rough bed of coarse sand on New Zealand's inner shelf. Results from that study and others like it (Green et al., 2004; Gutierrez et al., 2005) show that during storm conditions, turbulence increases 
over the rough beds, inhibiting settling of finer material, effectively enhancing the partitioning effect between the two types of sediment. These results support the positive feed-back loop suggested by Murray and Thieler (2004) as a sustaining mechanism for sorted bedforms. The present study combines all of these concepts and looks at how framework geology might influence nearshore bedforms, tying into earlier studies linking these bedforms to shoreline change (Schupp, 2005; McNinch, 2004).

\section{Paleo-channels}

Earlier seismic investigations in the study area show that the framework geology of the Northern Outer Banks and southern Virginia is not homogeneous but, rather, is laced with ancient fluvial and tidal inlet channels (Boss et al., 2002; Chen, 1992; Chen et al., 1995; Colman et al., 1990; Dame, 1990; Kimball and Dame, 1989; Riggs et al., 1995). Throughout Quaternary history, major glaciations have led to large-scale oscillations in global sea level (Boss et al., 2002; Fairbanks, 1989; Shackleton, 1987). The resulting regressions and transgressions have left their marks on the stratigraphic record in this area. During regressive episodes, when sea level was much lower than it is presently, fluvial systems cut across previously laid coastal plain and continental shelf strata, reworking older sediments and disrupting the normal horizontal pattern of bedforms (Belknap and Kraft, 1981; Chen, 1992; Hobbs, 2004; Rice et al., 1998; Riggs et al., 1995; Riggs et al., 1992; Roberts and Snyder, 2001), and making stratigraphic interpretation all the more challenging. When sea level rose again, the fluvial channels were inundated and backfilled with first fluvial, then estuarine and coastal sediments (Riggs and Belknap, 1988). 
Riggs et al. (1992) described the paleo-Roanoke-Albemarle system as a superposition of multiple channels with various degrees of preservation. The fluvial channels they mapped under the barrier island system and back bay area are filled first in their lower narrow reaches with fluvial sediments as sea level rises. This type of infill creates "chaotic depositional patterns" as displayed in the seismograms. The upper portions of the channels tend to be broader and the change to estuarine fill is evident by the more horizontal deposition patterns (Figure 2). Holocene tidal inlet channels may also be preserved in the framework geology and exhibit specific geometries and fill patterns in the seismic record that may help distinguish them from Pleistocene fluvial channels. Moslow and Heron (1978) described a distinct cross-sectional profile associated with preserved Holocene tidal inlets, a direct result of its lateral migration (Figure 3).

\section{Shore-oblique sandbars and gravel outcrops}

The shore-oblique sandbars and gravel outcrops described in this study may be related, in origin or maintenance or both, to inner shelf bedforms described in the literature. Many studies have documented large linear features, oriented oblique-toperpendicular to shore, characterized by alternating patches of sand and coarse sediment (for a complete listing, see Cacchione et al. (1984) and Murray and Thieler (2004)). Initially, due to the similarity of appearance, they were all labeled "rippled scour depressions" (RSD's). Some of the more well-studied RSD's on the west coast of the U.S. seem to be caused by cross-shore, downwelling currents which scour away finer sediment, exposing underlying coarser sediment (Cacchione et al., 1984). Recent 
observations on the east coast of the U.S., however, reveal stronger alongshore currents associated with similar features, which may start a self-organization and self-maintenance response (Gutierrez et al., 2005; Murray and Thieler, 2004). Given this difference in formation and maintenance, the current trend is to call the cross-shore, current generated features "sorted bedforms" (Murray and Thieler, 2004).

Previous studies of nearshore sandbars have highlighted different types of shoreoblique (or transverse) bars, but without the associated gravel outcrops that are seen in this study. The early work on transverse bars was categorized and summarized by Niederoda and Tanner (1970). Wright and Short (1984) described an intermediate morphologic surf zone state during which portions of crescentic bars weld to the beach to create transverse bars. Lippman and Holman (1990) used time exposure video to document the occurrence and frequency of different bar types. They, too, observed transverse bars, but of an unpredictable and ephemeral nature. Konicki and Holman (2000) identified trough transverse bars and offshore transverse bars. These were more stable than those identified by Lippman and Holman (1990) but showed a tendency to migrate alongshore.

Another class of features that share similarities with the shore-oblique bars observed in this study are inner shelf sand ridges. The occurrence of these sand ridges, or linear shoals, has been well-documented on the eastern coast of the United States (Duane et al., 1972; McBride and Moslow, 1991; Swift et al., 1972), as well as in other parts of the world (Snedden and Dalrymple, 1999; van de Meene and van Rijn, 2000). Duane et al. (1972) documented shared characteristics of Atlantic inner shelf ridges. They occur in groups, have up to $10 \mathrm{~m}$ of relief and are found in water depths between $3 \mathrm{~m}$ and $40 \mathrm{~m}$. 
Interestingly, regardless of the direction of the local longshore current, most of these Atlantic sand ridges open northward, forming an angle of no more than 35 degrees with the coastline. They tend to be over $1 \mathrm{~km}$ in length and have gently sloping sides (Duane et al., 1972; McBride and Moslow, 1991).

The present study explores the possible link between paleo-channels in the framework geology and overlying bathymetry and surface sediment characteristics in the nearshore. Objectives of this study are 1) mapping the underlying geology and surface sediment characteristics of the nearshore in several sites in northern North Carolina and southern Virginia, 2) using these data to identify the locations of relict channels, shoreoblique bars and gravel outcrops, 3) quantifying the spatial relationship between these features and 4) identifying characteristics of buried channels that may play an important role in controlling the presence of shore-oblique bars and gravel outcrops. 


\section{STUDY AREA}

\section{Physical setting}

135 line-kilometers were surveyed among four sites in southeastern Virginia and northeastern North Carolina (Figure 4) during the summer of 2003. The sites encompass portions of the nearshore regions of Sandbridge, Virginia (Figure 5) and Duck, Kitty Hawk (Figure 6) and Nags Head (Figure 7), North Carolina. These study sites vary in alongshore length but generally span the nearshore region between the $4 \mathrm{~m}$ and $15 \mathrm{~m}$ isobaths.

This section of the Virginia and North Carolina coastline is microtidal (Hayes, 1979) and storm dominated (Wright and Short, 1984). Tides are semidiurnal with a mean tidal range of $0.97 \mathrm{~m}$ (Birkemeier et al., 1985) and a mean spring range of $1.25 \mathrm{~m}$ (Wright and Short, 1984). The period of greatest storm activity occurs in fall and winter, and the majority of storms are extratropical with northeast winds. Most of the wave energy is from the east-northeast and northeast. (Wright and Short, 1984) Over the period from 1980-1989, average wave height during the summer months was $0.8 \mathrm{~m}$ and average wave height during the winter months was 1.2 meters. During the late summer and fall, extreme wave heights approached $7 \mathrm{~m}$ (USACE, 2005). 


\section{Geologic setting}

The study sites are located within the submerged extension of the coastal plain provinces of Virginia and North Carolina. While stratigraphic relationships can be difficult to reconstruct due to the low relief and low gradient of regional geomorphology (Boss et al., 2002), Riggs and others (1992) identified seven distinct Quaternary stratigraphic sequences in the back barrier region of northeastern North Carolina. The five upper sequences appear to correspond with those identified by Boss et al. (2002) offshore, absent any direct tying data in the nearshore. Studies in southeastern Virginia, however, identify only three to four major Quaternary sequences (Chen et al., 1995; Dame, 1990; Hobbs, 1990; Hobbs, 2004; Shideler et al., 1972). This difference may be attributable to the tectonic framework of the Atlantic Coastal Plain, which consists of a series of embayments and topographic highs. Southeastern Virginia is located on the Norfolk or Fort Monroe High and northeastern North Carolina is underlain by the Albemarle Embayment. Thinner sedimentary sections are typically associated with the highs, whereas sediment thicknesses are greater and the stratigraphic record usually more complete, in the embayments (Owens and Gohn, 1985). Alternatively, the difference in number of reported sequences may simply be the result of interpretation or equipment resolution (Hobbs, 2004).

The North Carolina study area is underlain by a series of tabular Quaternary strata sloping to the east-southeast (Boss et al., 2002; Riggs et al., 1992), which, in some locations, outcrop on the seafloor (Boss et al., 2002; McNinch, 2004; Rice et al., 1998; Riggs et al., 1992; Roberts and Snyder, 2001). The region is overlain by a thin layer of Holocene sand which thins in the seaward and southward direction (Rice et al., 1998; 
Riggs et al., 1995). Cutting through the Quaternary strata is a series of Pleistocene paleofluvial systems that have since been back-filled with Pleistocene and Holocene sediments following rising sea level. Boss et al. (2002) mapped multiple channels of the Roanoke Albemarle paleo-fluvial complex on the continental shelf (Figure 8) and managed to correlate them, with some degree of confidence (despite the lack of nearshore data), with those identified by Riggs and colleagues in the back barrier. In southeastern Virginia, two potentially separate major paleo-fluvial drainage networks have been mapped in the Chesapeake Bay and offshore (Chen et al., 1995; Colman et al., 1990; Dame, 1990; Hobbs, 1997; Oertel and Foyle, 1995). Beneath the Delmarva Peninsula and the modern Bay mouth, at least four distinct iterations of the paleo-Susquehanna have been identified (Colman et al., 1990; Hobbs, 1997; Hobbs, 2004; Oertel and Foyle, 1995). Exmore Channel, the oldest ( $200-400 \mathrm{ka})$ and northernmost, lies beneath the Delmarva Peninsula, approximately $50 \mathrm{~km}$ north of Cape Charles, VA. The progressively younger channels (Belle Haven, Eastville and Cape Charles) cut paths farther to the south, in succession. This southward migration of the paleo-Susquehanna is attributed to the barrier spit formation process of the Delmarva Peninsula during periods of interglacial sea-level high-stands. The resultant southward progradation of the peninsula forced the southward migration of the river's course (Colman et al., 1990; Hobbs, 2004; Mixon, 1985).

Offshore of Sandbridge, VA, in the vicinity of a documented long-term erosional hotspot (Hobbs et al., 1999), a separate paleo-fluvial system has been mapped (Chen, 1992; Dame, 1990; Hobbs, 1990; Kimball and Dame, 1989). This might be associated with the paleo-James River (or possibly the paleo-Elizabeth River) (Harrison et al., 1965; 
Meisburger, 1972; Swift, 1975) and there is speculation that it links up with the paleoRoanoke-Albemarle system farther offshore (Boss et al., 2002, Chen et al., 1995). Chen et al. (1995) identified three temporally-distinct paleo-channel systems (I-III), which presumably developed during the same lowstands as the Exmore, Eastville and Cape Charles Channels of the paleo-Susquehanna system. The youngest of these, System III, consists of channels oriented generally shore-normal and is most likely associated with features of the modern shoreline. The two older systems run more shore parallel and suggest analogs to the modern northeastern North Carolina sounds and southeastern Virginia's Back Bay, which are bounded by Pleistocene shorelines. 


\section{METHODS}

\section{Data collection and processing}

Surface sediment characteristics were mapped during June of 2003 using a $600 \mathrm{kHz}$ Marine Sonics side-scan sonar. These data were used to identify the locations of outcropping gravel patches. An Edgetech 512I Chirp sub-bottom profiler was used to map the underlying geology of the study areas. A range of frequencies $(0.5-6 \mathrm{kHz})$ allowed penetration of the nearshore Holocene sand layer, while resolving the acoustic layers to within $\sim 10 \mathrm{~cm}$. This allowed the identification of paleo-channels to depths of $\sim 20 \mathrm{~m}$ below the seafloor, as well as finer details of the infilled layers. Both the sidescan and seismic data were processed with SonarWeb Pro ${ }^{\mathrm{TM}}$ software, developed by Chesapeake Technologies.

Interferometric swath bathymetry data collected in 2002 were used to identify the locations of the shore-oblique bars. During that survey, outcropping gravel patches were found on the northern flanks of the bars. The side-scan data for this study (collected in 2003) were used to identify gravel patches and the locations of these were plotted on the bathymetric maps to compare the locations of the bar and outcrop fields. Using previously collected bathymetry data corroborated with current gravel outcrop data is justifiable given the recent findings of extremely high correlation between shore-oblique sandbars and gravel outcrops in the northern Outer Banks (Schupp, 2005; McNinch, 2004). Chirp seismic data also highlighted the bar locations, but only as a complement to 
the bathymetry and side-scan data, since seismic data collected with a towfish are not a reliable indicator of bathymetry. Channel locations were then plotted on the same map to give a visual indication of the spatial relationships between the various features.

\section{Statistical analysis}

To statistically analyze the relationship between the bar regions and paleochannels, two tests were applied. The first, chi square, was used to determine if a spatial relationship between the occurrence of shore-oblique bars and buried channels exists. Following a statistically significant result of the chi square test, cross-correlation was employed to test the strength of this relationship (Davis, 1983).

The chi square statistic tests how well a given set of observed data fits a uniform probability distribution of expected values (Evans, 2002). An arbitrary baseline was drawn parallel to shore and all bar fields and channels were traced in perpendicular to this line. Approximately every ten meters along this line, a simple presence / absence test was performed for bars and channels. If a bar or channel were present, a 1 was entered in the appropriate column in the spreadsheet, while absence of either resulted in a 0 . The results were put into a $2 \times 2$ contingency table and analyzed by the chi square method (Zar, 1999).

Before the cross-correlation test could be utilized, the 3-D bar and channel data had to be parameterized in order to run the 2-D analysis. Since appropriate methodology was not realized in the literature, the following method was developed to numerically represent and compare bathymetry and sub-bottom data. Bar metrics were created to allow the assignment of a numerical value to each bar based on certain dimensions. Bar 
area was determined by the product of the length of each shore-oblique bar and its width. In all cases, the index for each bar metric was the northing (spaced every 10m) from a "bar baseline" traced in Surfer"M (Golden Software) at approximately the $5 \mathrm{~m}$ isobath (Figure 9). The bar area was associated with the midpoint of each bar and values were interpolated between each bar midpoint, yielding a bar metric at each northing. Areas lacking bars were assigned a bar metric of 0 .

Each channel was digitized in the seismic record and the resultant depths were referenced to both the seafloor and the top of the channel (Figure 10). This was done to try to capture the importance of the depth of channel burial beneath the seafloor. A channel baseline was drawn in Surfer ${ }^{\mathrm{TM}}$ at approximately the $7 \mathrm{~m}$ isobath. Channel endpoints were plotted (coordinates taken from the cross-sections in the seismic record) and lines were drawn from these to the channel baseline (Figure 9). The channel depths (referenced to either the seafloor or the top of channel, depending on the test being run) were inserted at the appropriate northing along the channel baseline.

Cross-correlation analyses were performed in Matlab $^{\mathrm{TM}}$ (MathWorks) to quantify the spatial relationship between shore-oblique bars and paleo-channels. Three separate correlation analyses were run for each study site. The first two used the digitized channel depths referenced either to the overlying seafloor or the top of the channel (Figure 10). In the third analysis, the depth of burial beneath the seafloor (DBSF) was subtracted from the actual channel depth to investigate the effect of channel burial (Figure 10). A conservative approach was taken in determining sample independence and degrees of freedom for statistical significance assessments. Sample size (n) was based on the total number of channels plus the non-channel, or interfluve, areas on either side of each 
channel. Each channel and interfluve was assigned a sample size of $n=1$, regardless of channel width. For example, there were four channels in the Sandbridge region, so $n=9$; Kitty Hawk had 1 channel, so $n=3$; and Nags Head had 3 channels, so $n=7$. The same correlation analyses were also run for combined study sites, providing a sample size of $\mathrm{n}=17$.

\section{Error estimates}

The error associated with the acquisition of bathymetry data is $15-20 \mathrm{~cm}$ in both the horizontal and vertical (McNinch, 2004) while that associated with the collection of sub-bottom data is on the order of $1-2 \mathrm{~m}$ in the horizontal and $\sim 50 \mathrm{~cm}$ in the vertical. The subsequent processing of data (gridding, digitizing) introduces subjective error; however, the types of statistical tests applied and the questions asked here operate on much larger scales than the combined data acquisition and processing inaccuracies. 


\section{RESULTS}

\section{Observed shore-oblique bars, gravel outcrops and paleo-channels}

The three bar fields observed in the study sites lie on a continuum in terms of their characteristics (Figure 11, Table 1), with the Kitty Hawk bar field being the best developed and largest, that at Nags Head being substantially smaller, and Sandbridge falling between the two. The size of the bar field also appears to correspond to the number of gravel outcrops. Representative side-scan images of the outcrops from each site are shown in Figures 12 and 13. Bright yellow indicates areas of higher backscatter, or harder substrate. Earlier studies showed this harder substrate to be areas of coarse gravel and shell hash (McNinch, 2004; Schupp, 2005) characterized by wave-driven ripples. The ripples are interpreted to be influenced by waves since their axes are oriented parallel to the shoreline. The darker orange areas represent fine-grained sand (McNinch, 2004; Schupp, 2005).

The channels observed in the sub-bottom record exhibit the same trend as that of the bar fields, with the best preserved channel (most easily discerned in the seismic record) at Kitty Hawk and the least so at Nags Head. Representative channel crosssections from each study site are shown in Figures 14-16. The lines were run parallel to shore in varying water depths. The channel cross-sections from Sandbridge show a wellpreserved northern edge or cut-bank that becomes harder to identify farther to the south (Figure 14). The smooth flat-lying reflectors are indicative of estuarine back-filling 
(Riggs, 1995). At Kitty Hawk (Figure 15), the entire lateral course of the RoanokeAlbemarle paleo-channel is preserved at the $15 \mathrm{~m}$ isobath. And at Nags Head, while there appear to be vast areas of channel meandering and down-cutting, it is difficult to trace with certainty the entire extent of channel movement (Figure 16).

\section{Correlation of buried channels and nearshore outcrops/shore-oblique bars}

\section{Spatial correlation using mapped bathymetry and channel locations}

The shore-oblique bar and outcrop clusters were gleaned from the seismic record and side-scan data from the June 2003 data collection period and found to be consistent with the 2002 bathymetry. The 2002 bathymetry data were then overlain with the 2003 outcrop and channel locations. Figures 17-19 reveal a strong correlation between the bar and outcrop locations, further increasing the confidence in comparing the channel locations with bathymetry collected at a previous time. Graphical correlation can also be made between the bar and outcrop clusters and wide (>500 m) channels (Figures 17-19).

At the Duck study site there were no distinct channels or evidence of shoreoblique bars in the seismic record and no gravel outcrops in the side-scan record. The bathymetric survey of May 2002 did not cover this region, but a reconnaissance study in 2001 that did cover this area did not reveal any bars or outcrops (McNinch, pers.comm.)

\section{Differences in sub-bottom cross-sections}

Shore-normal and-oblique sub-bottom profiles reveal a trend that supports the correlation seen on the surface between larger channels and bar/outcrop regions. Figure 5 
shows a plan view of the Sandbridge region with the nearshore portion of the bar / outcrop cluster highlighted. The dotted blue lines represent the locations of the subbottom cross-sections shown in Figure 20. Results from the other study sites are shown in Figures 6 and 21 for Kitty Hawk and Figures 7 and 22 for Nags Head. (Note that a bathymetric feature resembling a shore-oblique bar field appears in the southernmost portion of the Nags Head site; since there were no gravel outcrops at this location, it is not being treated as a bar field as defined in this study.) Sub-bottom cross-sections that lie outside of the bar fields show low relief, horizontal beds, a typical stratigraphic signature for an undisturbed, transgressive barrier island. Those that lie within, or partially within the bar fields, however, have a vastly different look: chaotic, truncated reflectors and evidence of preserved channel meandering and down-cutting.

\section{Statistical correlation}

Figure 23 is a graph of paleo-channels and bar metrics plotted against location (northing, UTM). Since the plotted channel data show sub-bottom topography and the bar data reflect the metric (bar length $\mathrm{x}$ width at center point and interpolated to edges), magnitudes cannot be compared directly. However, a spatial relationship between the two features is immediately apparent. The results of the chi square test reveal a strong spatial relationship between shore-oblique bars and channel location. Table 2 shows the $2 \times 2$ contingency table that was analyzed. For 1 degree of freedom, the significant chi square value at the $0.1 \%$ confidence level is 10.83 , meaning that for 1 degree of freedom, the probability that chi square is greater than 10.83 is 0.001 . In other words, fewer than 
$0.1 \%$ of trials would give a value greater than 10.83 if the sample is truly from a uniform distribution. Our chi square value was 949.98 , indicating that the result is highly significant.

Cross-correlation analyses comparing the locations of the bar/outcrop areas with the channel locations resulted in the correlation coefficients presented in Figures 24-27 and summarized in Table 3. For the most part, correlations are comparable whether the channel depth is referenced to the seafloor or the top of the channel. An exception is Sandbridge, which had one of the most deeply buried channels. In all cases, correlations were lowest when the effect of channel burial depth was considered. 


\section{DISCUSSION}

\section{Correlation of shore-oblique bars/outcrops with paleo-channels}

Shore-oblique bars and gravel outcrops in the nearshore correlate strongly with paleo-channels buried beneath the nearshore Holocene sands. This finding is notable because the same bathymetric features previously have been linked to shoreline hotspots(McNinch, 2004; Schupp, 2005). Whether there is a causal relationship involved (between bars and shoreline change, between paleo-channels and bars, etc.) or all phenomena are the result of some other common mechanism remains unclear. Nevertheless, the contribution of this finding lies in the establishment of a connection between relict framework geology and nearshore bedforms in a wave-dominated, energetic setting. Shore-oblique bars and gravel outcrops in the Outer Banks study sites appear to be relatively stable over several years of study, wherein the overall position of the bars remain in a fixed position with small-scale movement (wagging) in the shallowest (Schupp, 2005; McNinch, 2004). This is noteworthy because acoustic profiles and vibracores (McNinch et al., 2001) indicate that the bars are composed of unconsolidated sand with the same characteristics as the surrounding nearshore and beach; yet they persist in the same locations despite the high wave energy. It is suspected that this stability, as well as the origin, may be linked to the underlying geology of the nearshore. These bars are not interpreted as erosional features since they show no evidence of truncated bedding, but rather are acoustically transparent. This study was 
designed simply to investigate the potential spatial correlation between shore-oblique bar fields and channel locations. Although the present work demonstrates a statistically significant relationship between the bar/outcrop regions and underlying paleo-channels, the nature of a potential causal relationship is not addressable from these data. Nonetheless, the fact that they are spatially related may give insight into the mechanisms responsible for their existence.

The spatial relationships were assessed both visually and quantitatively. A plan view of each study site overlain by the locations of the bar/outcrop regions as well as the buried channels (Figures 17-19) demonstrates that all of the gravel outcrops and most of the channels are found in close proximity to the shore-oblique bars, suggesting high spatial correlation. This relationship is further strengthened by the nature of the seismic reflection profiles that fall within and outside of the bar areas. In all cases, there is a distinct difference between the sub-bottom cross-sections lying within the bar/outcrop region. The seismic lines which lie well outside these regions show a typical onshoreoffshore sub-bottom profile: gently sloping, low relief, horizontal strata (Figures 20-22). The seismic lines which cross through and seaward of the bar/outcrop regions, however, display very distinct chaotic reflector patterns, likely indicating reworking of older strata by the meandering and down-cutting of Pleistocene rivers or relict tidal inlets. Simply put, evidence of prior reworking by a relict channel is found in all of the bar/outcrop regions. For example, in the Kitty Hawk site's seismic line (B-B') which lies outside of the bar region in the northern half of the study site and falls seaward of the bar region at its southern end (Figure 6), the reflectors on the northern end of the line are parallel and gently sloping, while the reflectors at the southern end show no such order (Figure 21), 
once again strengthening the connection between channel location and the shore-oblique bars and outcrops.

A chi square test was used to determine whether a significant quantitative relationship exists between the locations of the bar clusters and underlying channels (Table 2). The results of this test revealed a strong relationship between the locations of the two types of features. The chi square value of 949.98 was orders of magnitude higher than the significant value of 10.83 at the $0.1 \%$ confidence level. In order to quantify this spatial relationship, a cross correlation analysis was used to compare the bars and channels at each study site individually, and across the study sites as a whole (Figures 2427, Table 3). The correlations were statistically significant at the $1 \%$ confidence interval for the collective study sites and the Sandbridge site. While the correlation coefficients were relatively high at the Kitty Hawk and Nags Head sites, the conservative method of determining sampling size (total of interfluve and channel areas) did not render them statistically significant.

Following the establishment of a spatial correlation, the channels were scrutinized to determine distinguishing features of those that appear to correlate more closely with the bar regions. Figures 17-19 reveal that the channels that lie closest to the bar/outcrop areas tend to have the widest cross-sections. Further, where channels are better defined acoustically with distinctive reflectors showing downcutting and back-filling (e.g. Kitty Hawk and Sandbridge sites), bar fields are larger. In contrast, Nags Head, which has large areas of chaotic reflectors, but less definition, has the smallest bar fields. This suggests that while channel width seems to be the most important parameter in determining bar location, the size of a bar field might be related to the level of definition 
of the channel reflectors. This level of definition might be due to lithologic differences between fluvial channel fill and migrating tidal inlet fill. Greater density differences between fluvial channel fill types would result in higher reflection coefficients and more pronounced seismic reflectors. The major channels follow this trend with those at Sandbridge and Kitty Hawk potentially tied to the paleo-James and paleo-RoanokeAlbemarle, respectively and that at Nags Head perhaps associated with the historic Roanoke Inlet, which was open between 1585 and 1817 and migrated at least $4 \mathrm{~km}$ during that span (Fisher, 1962; Riggs et al., 1995).

Since it seems intuitive that, all other things being equal, a channel that is more deeply buried will have less of an influence on overlying sediments, another cross correlation comparison was performed after subtracting the amount of burial (DBSF) from the real channel depth (Figure 10). While this was done at the scale of an entire site, rather than that of individual channels, it might yet prove to be a useful indicator since the site with the most deeply buried channel (Sandbridge) showed the lowest correlation for this comparison (Table 3). The depth at which a channel is buried beneath the seafloor cannot in and of itself be used as a diagnostic, since it is dependent in part on sampling location; closer to shore, the Holocene sand is thicker so the same channel will be more deeply buried than it is farther seaward. It could be used for a relative comparison, however, for perhaps looking at two different channel cross-sections that lie along the same isobath. Even though some channels are more deeply buried and may not directly influence the overlying bathymetry, they may still provide insight. If they are older iterations of overlying paleo-fluvial systems, they will most likely correlate 
spatially, so width still seems to be the most important parameter in determining influence on surface expression.

\section{Prospective field and management applications}

The larger paleo-channels in the seismic record showed high spatial correlation with the locations of nearshore bar/outcrop fields. While the processes that might cause or influence such a relationship are still unknown, the importance of this connection is immediately applicable in shoreline management practices. For example, Boss et al. (2002) provide a map of paleo-channels on the inner shelf of northern North Carolina. We mapped the nearshore portion of one of these thalwegs at our site in Kitty Hawk, NC. This is the location of the largest bar/outcrop region and best-defined channel (presumably the paleo-Roanoke-Albemarle River), as well as a long-term erosional hotspot. We also mapped the nearshore region of Sandbridge, VA, where a large channel complex has been identified offshore (Chen et al., 1995; Dame, 1990; Hobbs, 1997; Kimball and Dame, 1989). Like the previous example, this site is characterized by a well-defined channel, large bar region and shoreline hotspot. If the shoreline erosion at these locations is attributable to the underlying channels, then it stands to reason that in similar environments, one might be able to trace channels mapped on the inner shelf into shore to predict areas susceptible to erosion. In other words, it might be possible to make educated guesses about shoreline erosion using data that already exist in the literature.

A simple test of this method was done with Hine and Snyder's (1985) map of paleo-channels in Onslow Bay, NC. Figure 28 shows the locations of their mapped channels coupled with shoreline change rates from 1998 (more recent rates were not used due to substantial beach nourishment.) The shoreline change rates for Bogue Banks show 
four main areas of erosion. Hine and Snyder (1985) mapped two major channels on the inner shelf that can be traced inshore. The westernmost channel corresponds well with the area of erosion just east of Bogue Inlet. The easternmost channel appears to have several iterations closer to shore, two of which are still seen in their innermost seismic line. There is a smaller channel that lies in the vicinity of Beaufort Inlet, but the erosion here is more likely attributable to inlet dynamics. Overall, there are four channels discernible landward of the $10 \mathrm{~m}$ isobath, all of which lie near one of the four main areas of beach erosion.

This is not to suggest that such associations between paleo-channels and erosionprone regions of shoreline will always apply. Nor are we suggesting that paleo-channels will always be associated with shore-oblique sandbars and vice versa; indeed, this was not always the case in our data. However, the established spatial relationship between buried channels with nearshore bedforms and shoreline erosion in the northern Outer Banks and southern Virginia and the apparent similar association found in Onslow Bay suggest sub-bottom mapping of inner-shelf paleo-channels may prove to be a useful guide for predicting the location of future erosion-prone areas. Ultimately, the primary scientific goal is to illuminate the mechanisms involved in this relationship, but the potential applications that have resulted thus far are compelling.

\section{Prospective mechanisms}

The idea that a buried feature could possibly have any influence on nearshore morphodynamics is contrary to the widely accepted concept of shoreface slope and bedforms responding simply to wave energy and mean sediment size (Komar, 1998; 
Pilkey et al., 1993). The spatial association suggests a more complex picture, one in which other variables such as sediment heterogeneity (vertical and horizontal) and seabed roughness gradients (which, in turn, may be dictated by paleo-channels), may play an important role in bar morphodynamics and beach erosion.

One possible explanation for the spatial relationship between buried channels and shore-oblique bars in the nearshore is submarine groundwater discharge (SGD) (Corbett et al., 2001). A lens of freshwater accumulated from rainwater underlies barrier islands. It is well known that these freshwater reservoirs can seep into the marine environment where the fresh groundwater first encounters interstitial saline water in the nearshore (Valiela et al., 1990). It is possible that channel fill sediments might act as an aquitard (compact estuarine muds) or as a conduit (coarse-grained fluvial gravel) for groundwater. Inspection of channel cross-sections in the seismic record reveals definite lateral heterogeneity. While it is only speculation until coring has occurred, perhaps some of this heterogeneity is due to alternating coarse and fine sediments. Coarser sediment could have been left near the top of the channel at the initial cut-bank or at a point bar after the river continued to migrate. Finer sediments would have back-filled the available accommodation space during transgression (Belknap and Kraft, 1985). If freshwater discharge is higher at the locations of the more porous, coarse-grained sediments, perhaps it could alter sediment transport potential. The overlying Holocene sediments at these locations would have increased interstitial water content and thus increased porosity, making them more easily erodible, perhaps resulting in the formation of irregular bathymetric features. 
Another possible explanation for the correlation between paleo-channels and shore-oblique bars is the exposure of channels farther offshore where the overlying sediment layer is thinner. The various lithologies exposed, ranging from fine-grained, compact estuarine muds to coarse fluvial gravels, could create roughness gradients and/or bathymetric irregularities leading to an influence on waves. Ardhuin et al. (2003) showed that heterogeneity of surficial sediments could, in fact, impact waves as they propagate across the shelf, and many have shown the influence of holes (Bender and Dean, 2003) or highs (Cox et al., 1995) on wave direction near the beach. Presumably, alteration of the incident wave energy could result in alongshore gradients in nearshore sediment transport(Ashton et al., 2003). This may possibly explain different bar formations and spatial variations in beach erosion, but the presence of persistent outcropping gravel patches in the nearshore remains unexplained. Furthermore, nearshore sand volume calculations in this region, indicate that such gradients have not resulted in significant alongshore sand volume variations (Miselis and McNinch, 2002; 2003).

Another plausible scenario also involves exposure of channel fill, but in the nearshore region rather than farther out on the shelf. During high energy conditions, upper layers of Holocene sand get stripped away in the nearshore, exposing underlying surfaces of differing lithology (Pearson, 1979; Thieler et al., 2001). Where these surfaces are composed primarily of coarse gravel (such as from relict riverine point bars), larger turbulent eddies form, inhibiting the settling of finer-grained material, as was described by Green et al. (2004). The exposure thus initiates a self-sustaining feed-back mechanism as described by Murray and Thieler (2004) such that coarse rippled beds 
inhibit settling of fine material, thereby sustaining and increasing the partitioning effect between the two grain sizes. Unlike the previous hypothesis, this one explains both the location of the bar fields, and the gravel exposures on the updrift flanks of the bars. This could be initially tested with densely-spaced cores across the width of a channel. The close spacing would capture cross-channel heterogeneity and determine if channel-fill gravels can be found close to the seafloor, and are thus a plausible source material for this mechanism. A combined hydrodynamic and sediment transport study would be necessary, however, to thoroughly test this hypothesis. 


\section{CONCLUSIONS}

Results from this study show the following:

1) Underlying, relict channels in the nearshore correlate spatially with regions of shore-oblique bars and gravel outcrops. Because the bar and outcrop regions previously have been linked to erosional hotspots, this finding has direct bearing on shoreline management.

2) Underlying channel size width is the most important factor in determining presence of a shore-oblique bar field.

3) Size of a bar region may be dictated by lithology of fill material; larger bar fields may form over relict fluvial channels while smaller bar regions may be associated with tidal inlet channels.

Evidence for the relationship between paleo-channels and shore-oblique bar regions was presented both in the form of qualitative spatial data, as well as through the application of statistical tests. A new method of quantifying bathymetry and seismic data for the purpose of making spatial comparisons was presented. The method is straightforward and could be applied in any situation where a spatial relationship between different 3-dimensional features is being compared.

Another application of these results involves using paleo-channel locations to predict erosion-prone areas of shoreline. In the region investigated in this study 
(southeastern VA and the northern Outer Banks of NC) three shore-oblique bar/outcrop clusters with associated erosional hotspots were identified. Each bar region was underlain by a large paleo-channel. From this, it was surmised that a first-order approach to identifying potential erosional hotspots would be to trace previously mapped channels into shore. A cursory test of this method was performed with published data from Onslow Bay, NC. Comparing channels mapped on the inner shelf with shoreline change data revealed that all four channels discernible landward of the $10 \mathrm{~m}$ isobath lie near the four main areas of beach erosion on Bogue Banks.

Several possible mechanisms were proposed to explain the correlation between shore-oblique bars fields and paleo-channels, including submarine groundwater discharge modifying the hydrodynamic environment, and the exposure of coarse channel fill and resultant self-organization of bedforms. While illuminating the precise mechanism will require further study and coring efforts, the results thus far provide immediate and important management applications. 


\begin{tabular}{l|lll} 
& Nags Head & Sandbridge & Kitty Hawk \\
\hline Barfield width $(m)$ & 1500 & 6000 & 6500 \\
Cross-shore length $(m)$ & 500 & 800 & 1000 \\
Maximum relief $(m)$ & 2 & 2.5 & 3
\end{tabular}

Table 1. Summary of average characteristics for each bar field. 


\begin{tabular}{|c|c|c|c|}
\hline & Channels & No Channels & Total \\
\hline Bars & 1281 & 397 & 1678 \\
\hline No Bars & 336 & 1198 & 1534 \\
\hline Total & 1617 & 1595 & 3212 \\
\hline & $\begin{array}{l}\text { Degrees of fre } \\
\chi 2=949.98 \\
p<0.001\end{array}$ & dom $=1$ & \\
\hline
\end{tabular}

Table 2. $2 \times 2$ contingency table for chi square analysis showing the frequency of occurrence of bars and channels. Presence / absence determinations for bars and channels were made every $10 \mathrm{~m}$ in the alongshore direction for each study site. 


\begin{tabular}{llll} 
Study Site & $\begin{array}{l}\text { Channel depth } \\
\text { referenced to } \\
\text { seafloor }\end{array}$ & $\begin{array}{l}\text { Channel depth } \\
\text { referenced to top } \\
\text { of channel }\end{array}$ & $\begin{array}{l}\text { Incorporating } \\
\text { importance of } \\
\text { channel burial }\end{array}$ \\
\hline Sandbridge & 0.7991 & 0.494 & 0.4374 \\
Kitty Hawk & 0.7413 & 0.7029 & 0.639 \\
Nags Head & 0.6621 & 0.6679 & 0.551 \\
All Sites & 0.6359 & 0.7124 & 0.6082
\end{tabular}

Table 3. Correlation coefficients resulting from cross-correlation analyses between paleo-channels and shore-oblique sandbar/gravel outcrop regions. Analyses were run using channel depths determined in three different ways: referenced to the seafloor, referenced to the top of the channel cross-section and finally, a depth measurement which subtracts the amount of burial (DBSF) from the channel depth. 


\section{Figure 1}

A sequence of nearshore bathymetry collected at the Kitty Hawk, North Carolina site that encompasses a region characterized by a smooth, convex shoreface adjacent to large, shore-oblique sandbars and troughs. (A) Three-dimensional block diagram of depths measured after Hurricane Isabel in November 2003. (B) November color bathymetry with March 2003 bathymetry (post-northeaster storm) overlain as white contours. (C) May 2002 bathymetry (fair weather), shown as white contours, with the November 2003 colored bathymetry. The large-scale morphology and position of these shore-oblique features remained similar after each fair-weather and post-storm survey. From McNinch, 2004. 


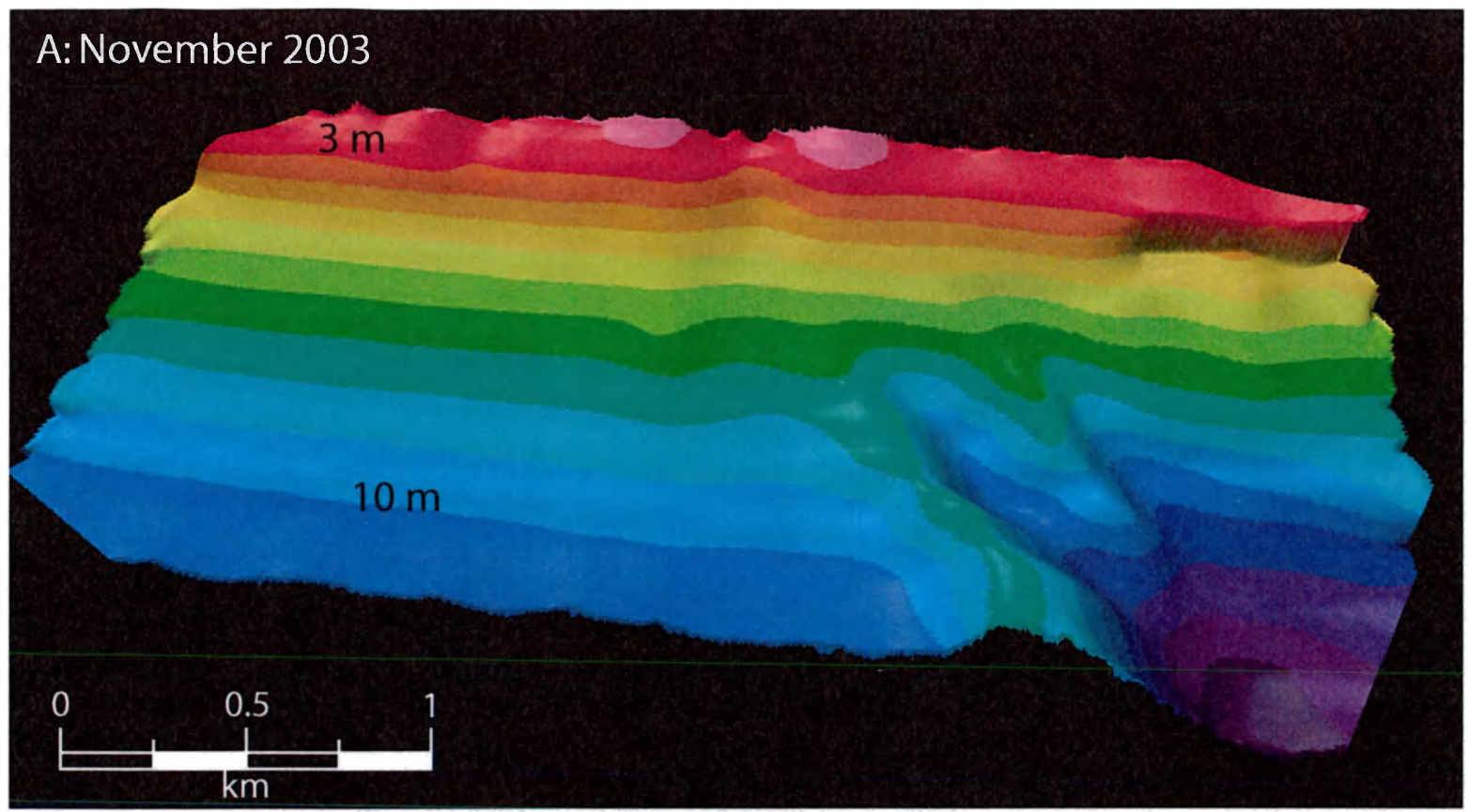

B: November 2003 with March 2003 contour overlay

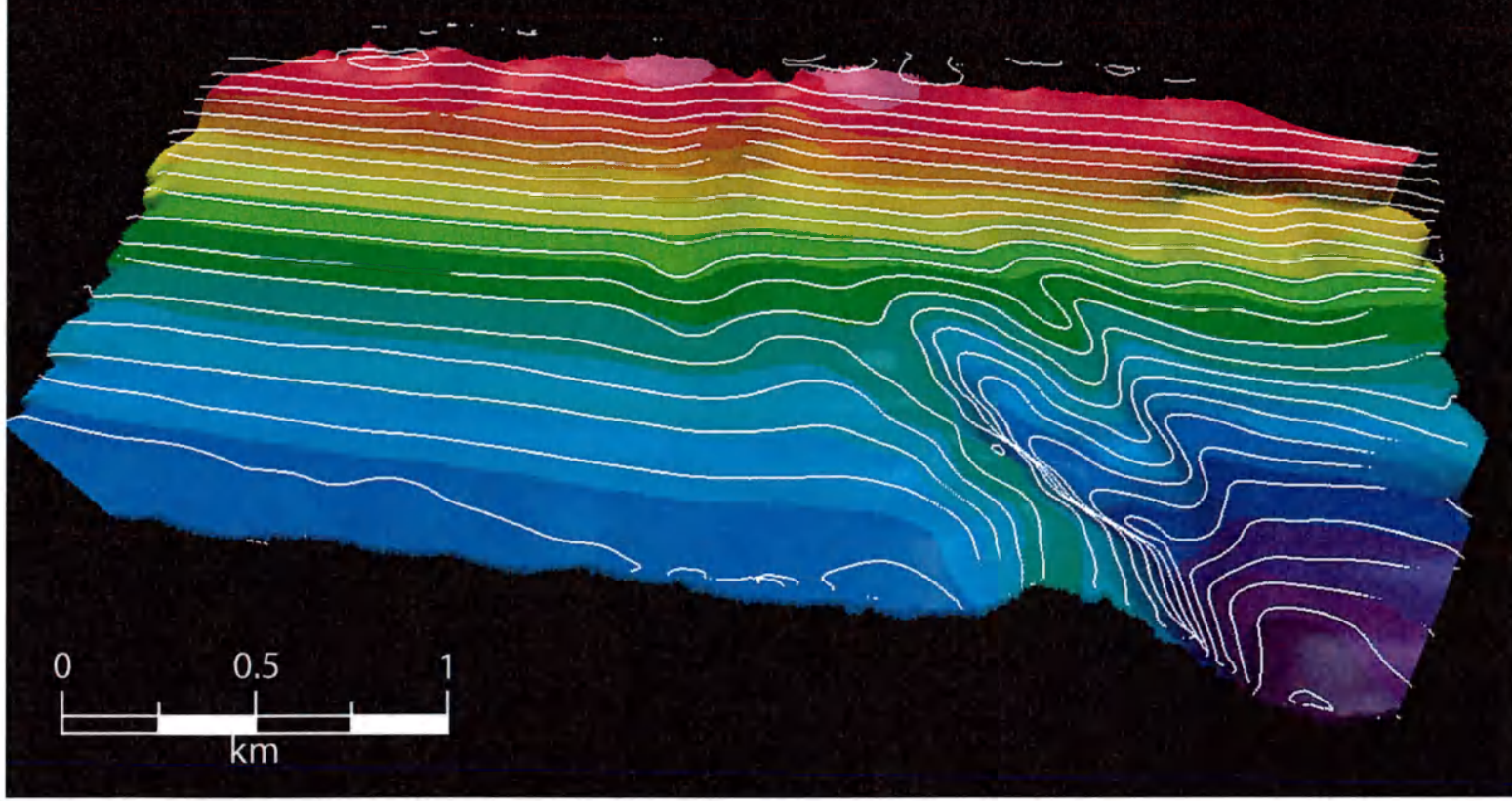

C: November 2003 with May 2002 contour overlay

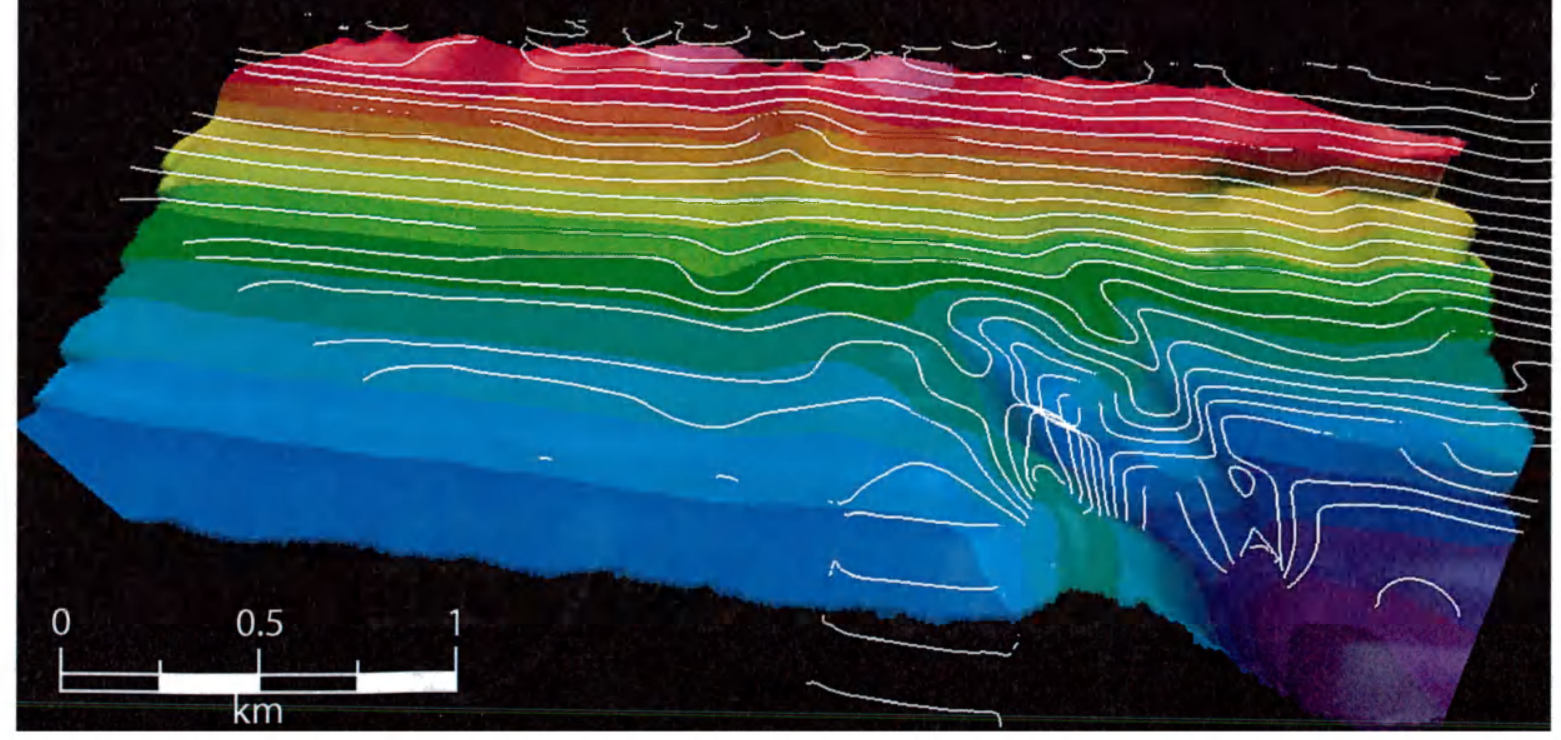


Figure 2

A chirp cross-section of a channel mapped in the nearshore of Kitty Hawk, NC, perhaps the main thalweg of the paleo-Roanoke-Albemarle fluvial system. Despite vertical exaggeration, it is evident that the upper layers of channel fill are more gently sloping, suggesting the presence of estuarine muds and clays resulting from transgressional backfilling. 


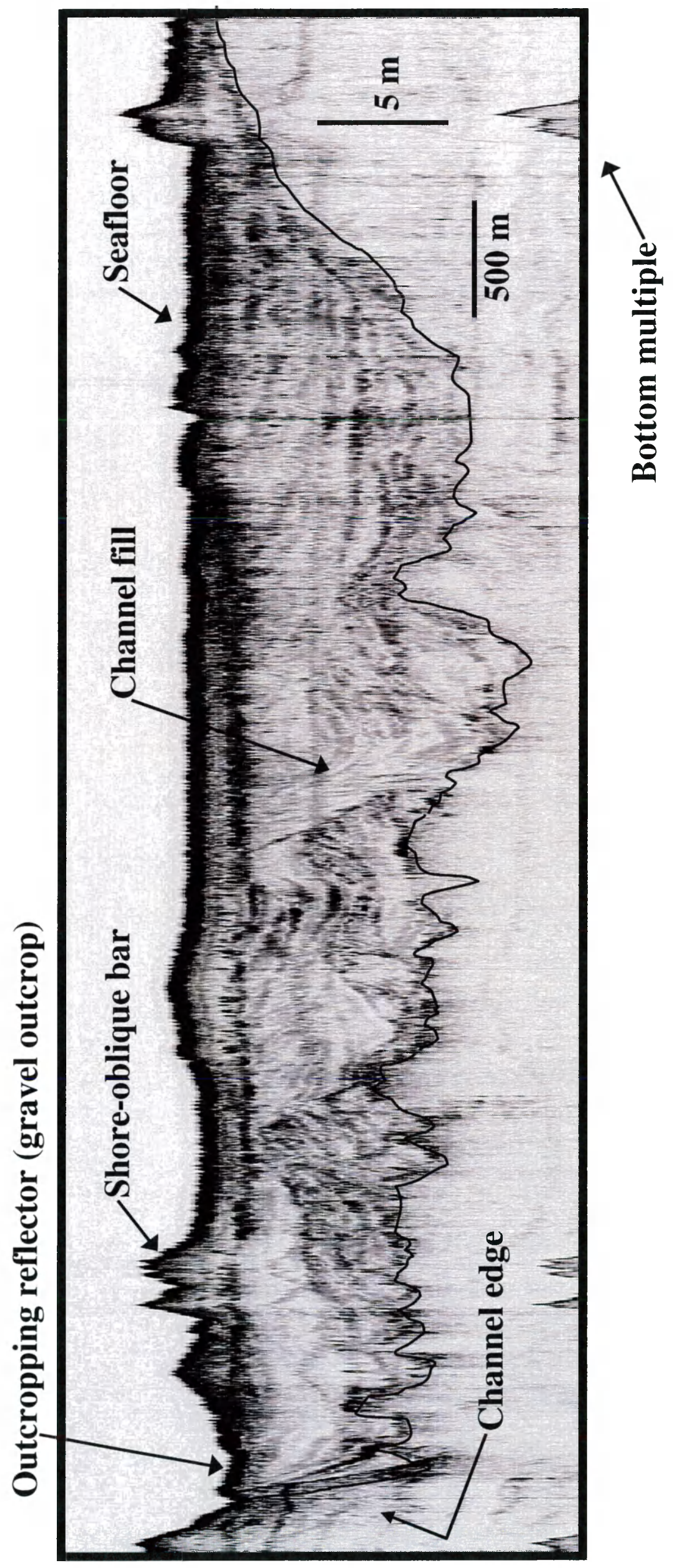




\section{Figure 3}

Panel A: Schematic of relict tidal inlet cross-section following Moslow and Heron (1978). Panel B: Chirp seismic cross-section from the nearshore region of Sandbridge, VA. 


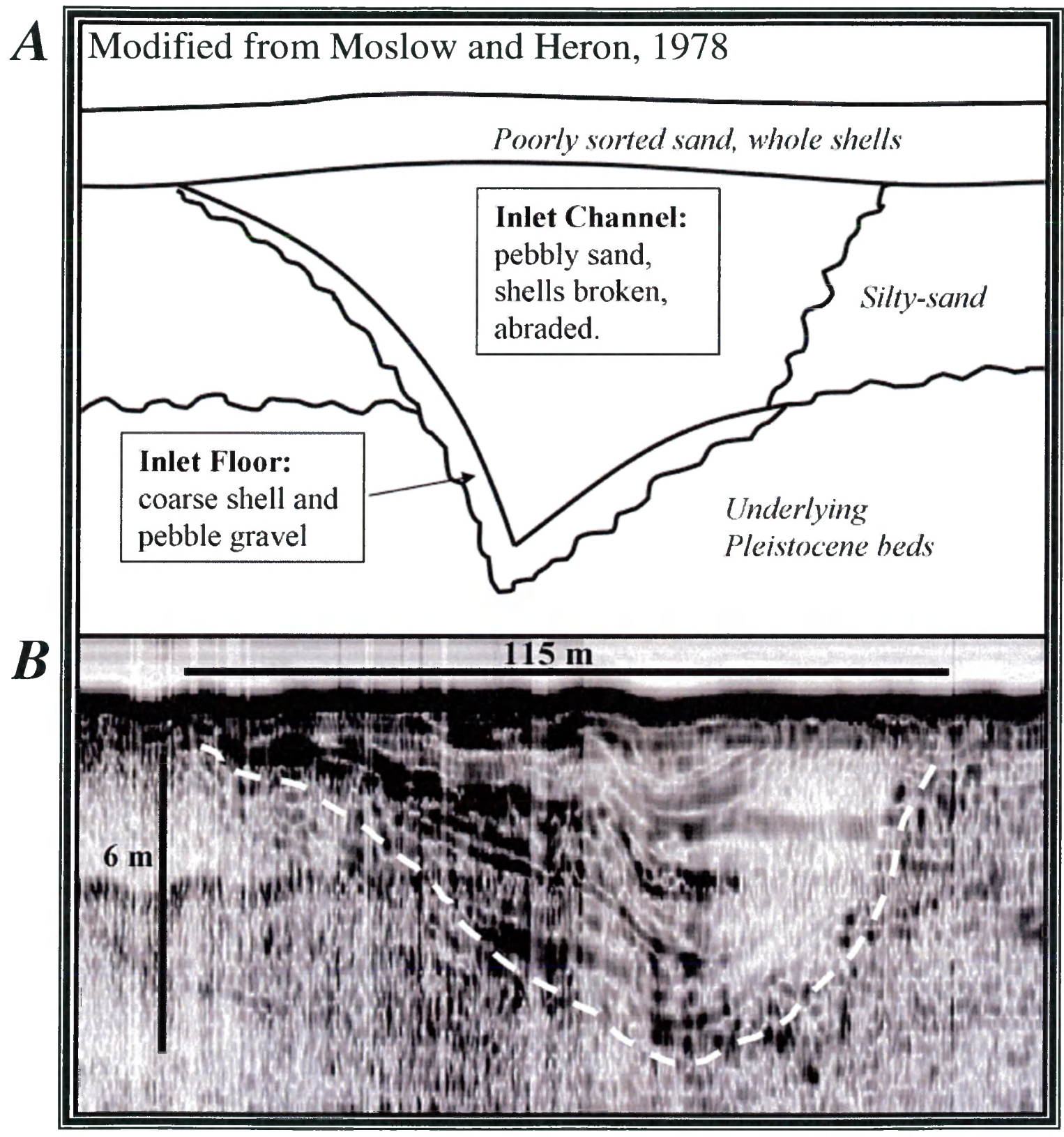


Figure 4

Location of study sites in southeastern Virginia and northeastern North Carolina. 


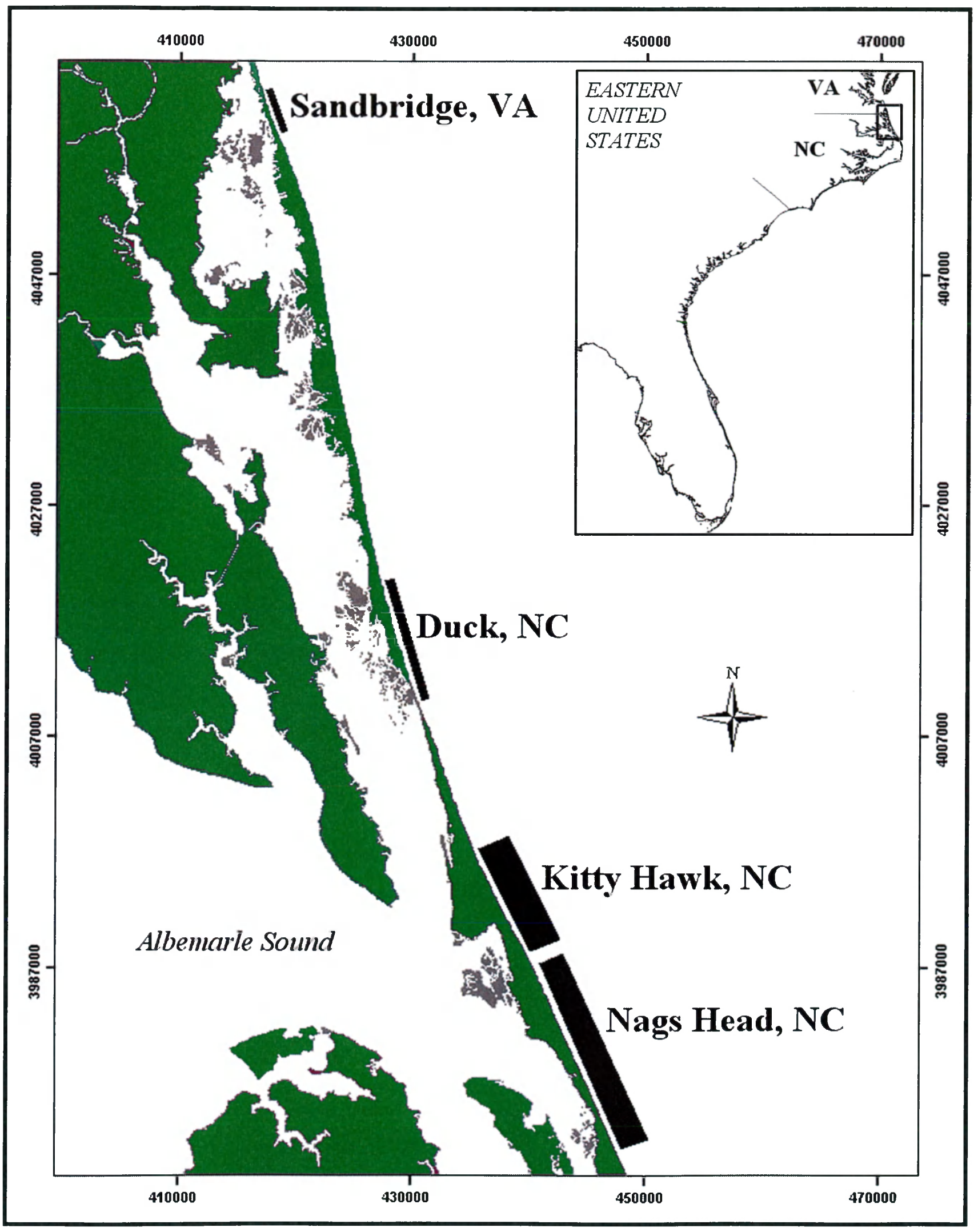




\section{Figure 5}

Bathymetry from Sandbridge, VA site overlain with navigation lines (solid red lines), locations of channel cross-sections shown in Figure 14 (dotted yellow lines), locations of gravel outcrops shown in Figure 12A (green dots), and locations of sub-bottom crosssections shown in Figure 20 (dotted blue lines). 


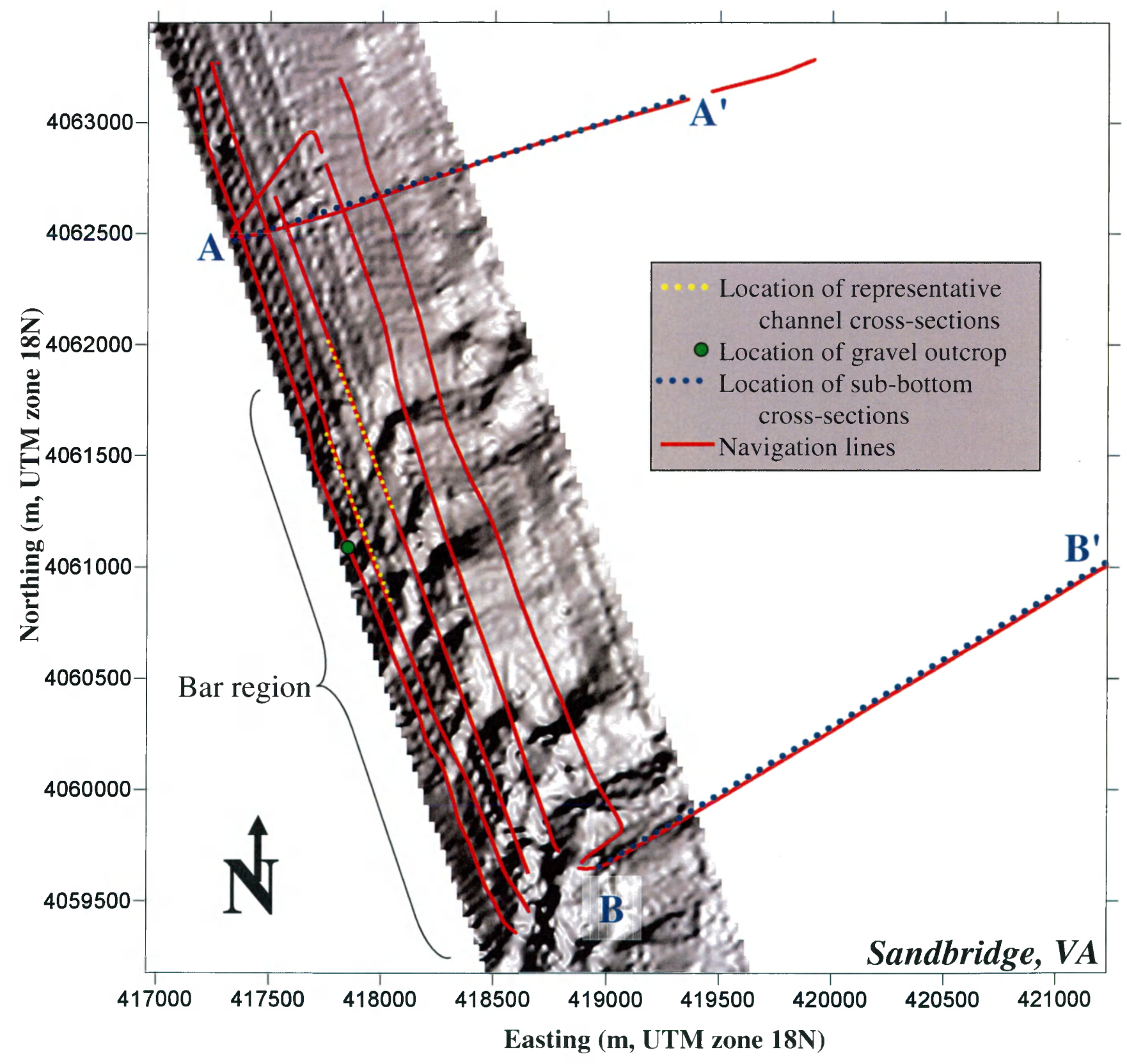




\section{Figure 6}

Bathymetry from Kitty Hawk, NC site overlain with navigation lines (solid red lines), locations of channel cross-sections shown in Figure 15 (dotted yellow lines), locations of gravel outcrops shown in Figure 12B (green dots), and locations of sub-bottom crosssections shown in Figure 21 (dotted blue lines). 


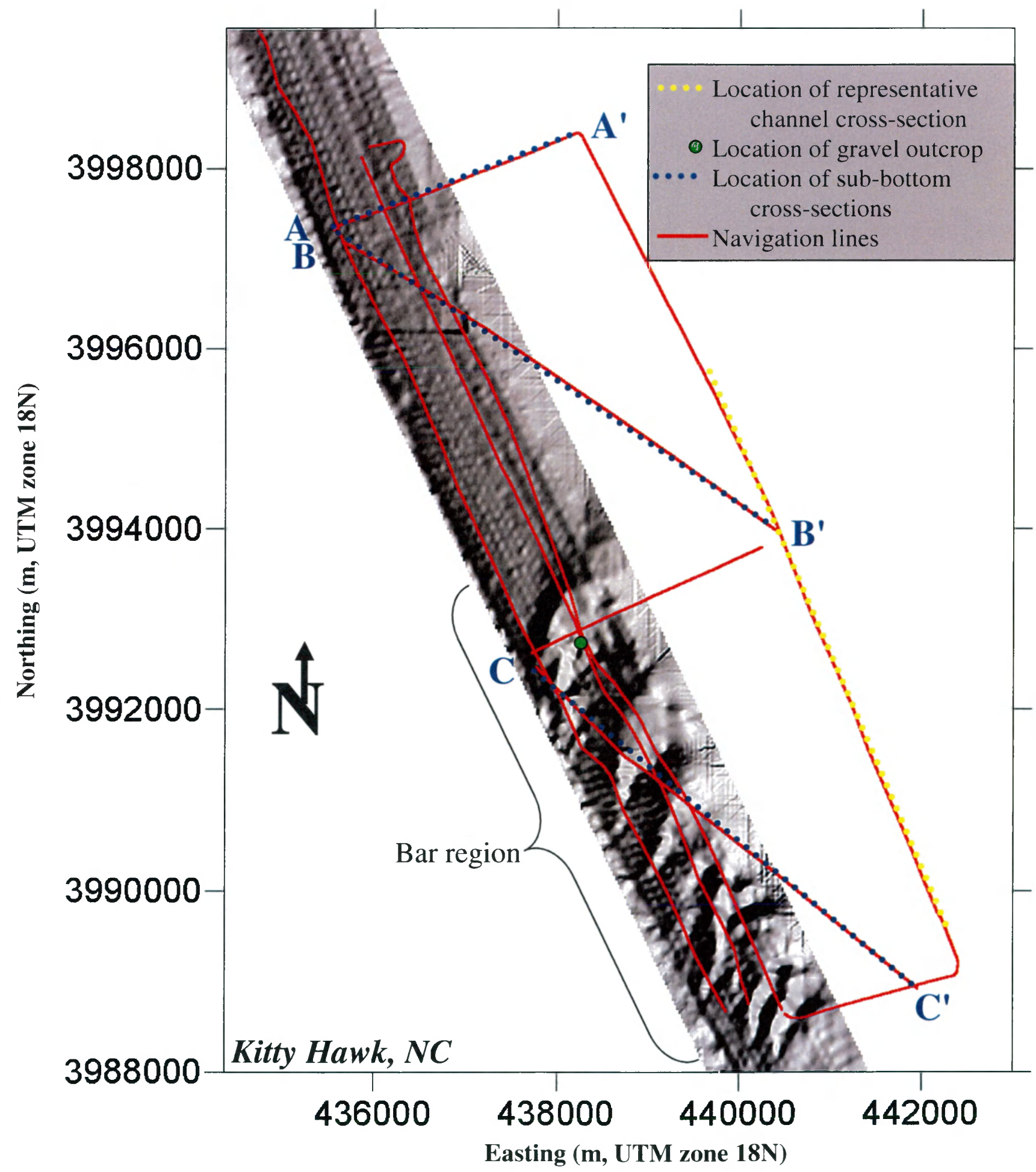




\section{Figure 7}

Bathymetry from Nags Head, NC site overlain with navigations lines (solid red lines), locations of channel cross-sections shown in Figure 16 (dotted yellow lines), locations of gravel outcrops shown in Figure 13 (green dots), and locations of sub-bottom crosssections shown in Figure 22 (dotted blue lines). 


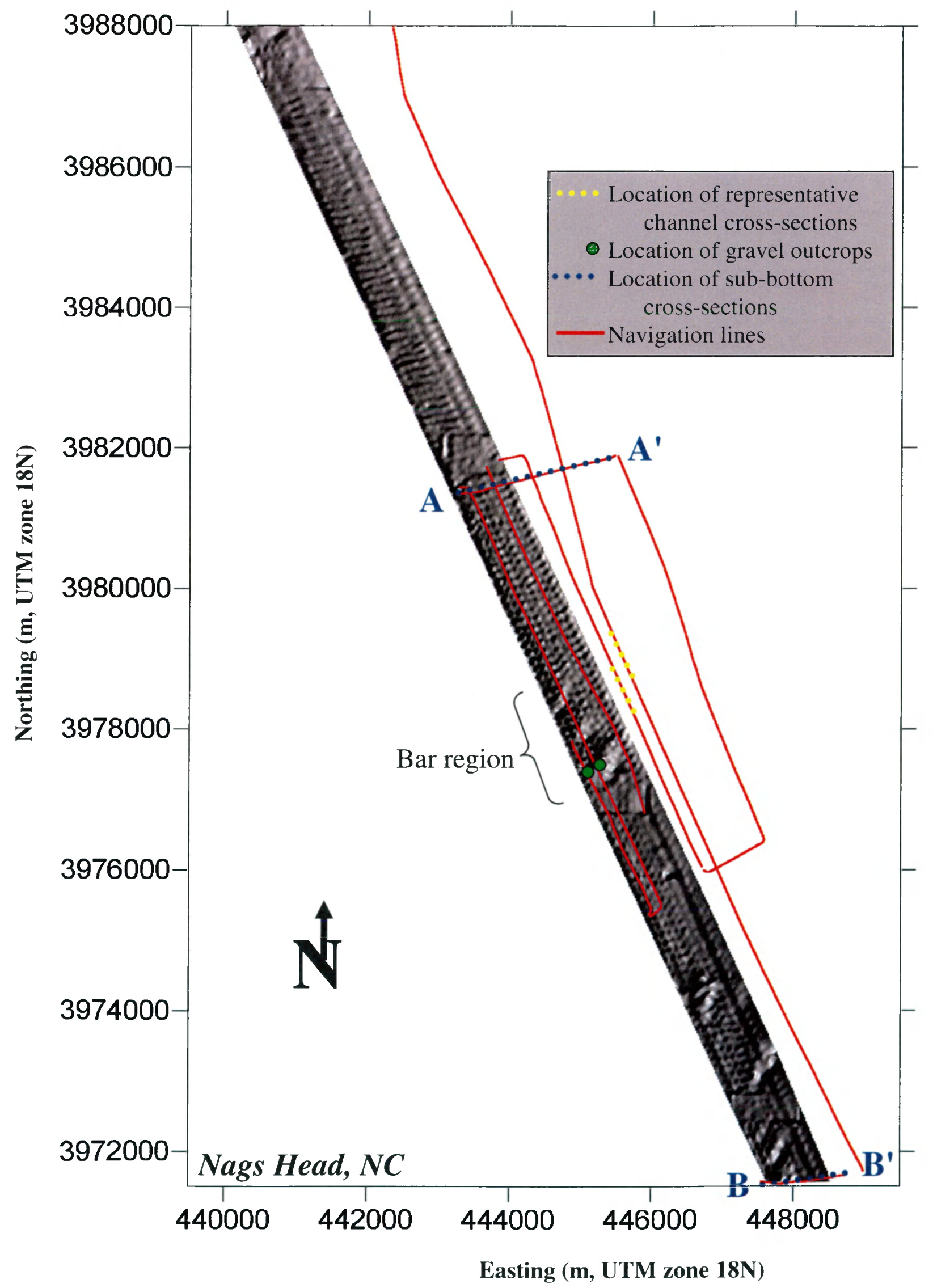


Figure 8

Outline of paleo-Roanoke-Albemarle fluvial system mapped on the continental shelf off of northeastern North Carolina. From Boss et al., 2002. 


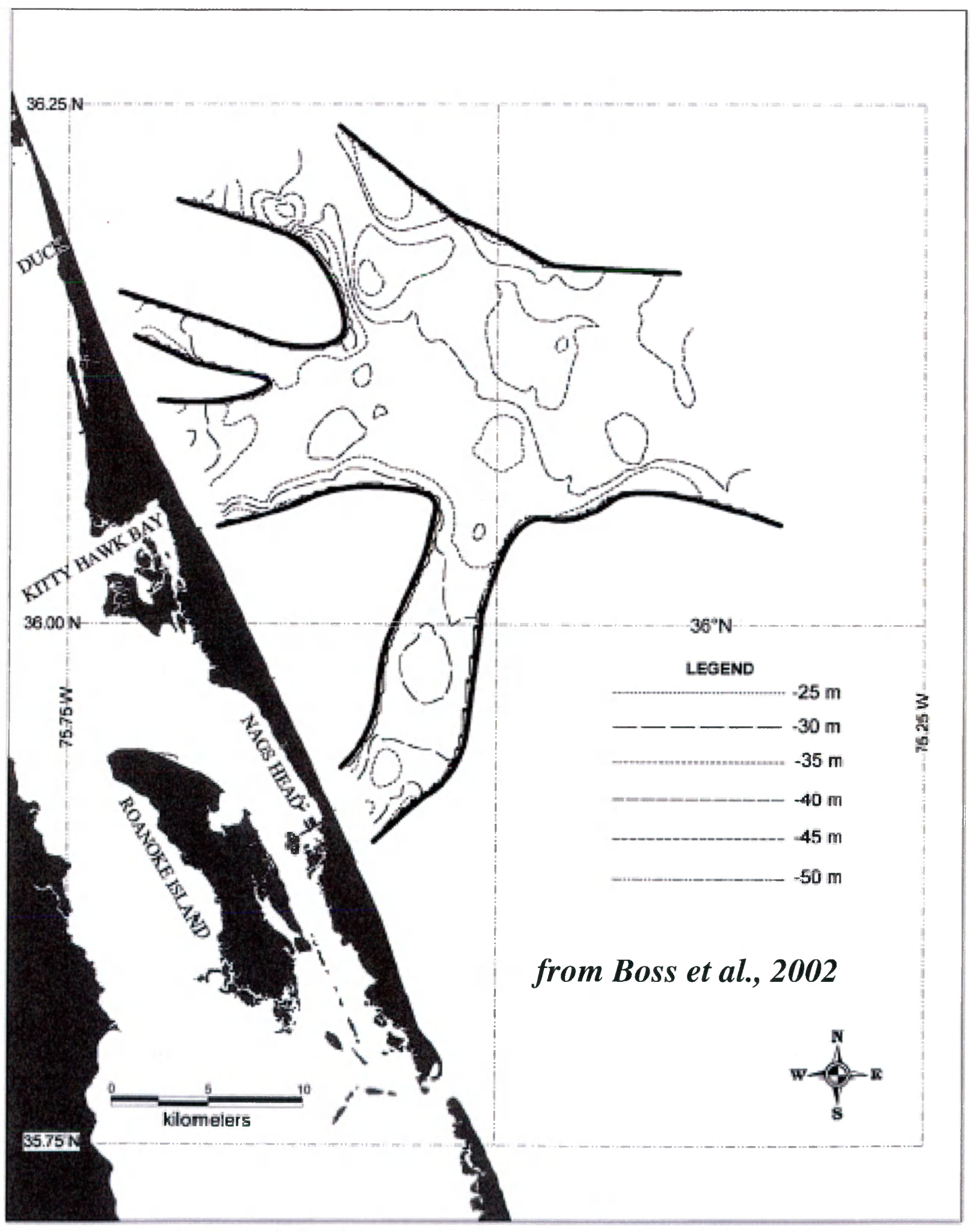


Figure 9

Schematic showing the methodology of determining and quantifying bar and channel parameters. Channel and bar endpoints were traced to an arbitrary channel and bar baseline, respectively. Every 10 meters along the channel baseline, a bar metric and channel depth were compiled in a spreadsheet. Bar metrics were based on length $(\ell)$ and width ( $\boldsymbol{\omega})$ of each bar. (See Methods section for more complete description). 


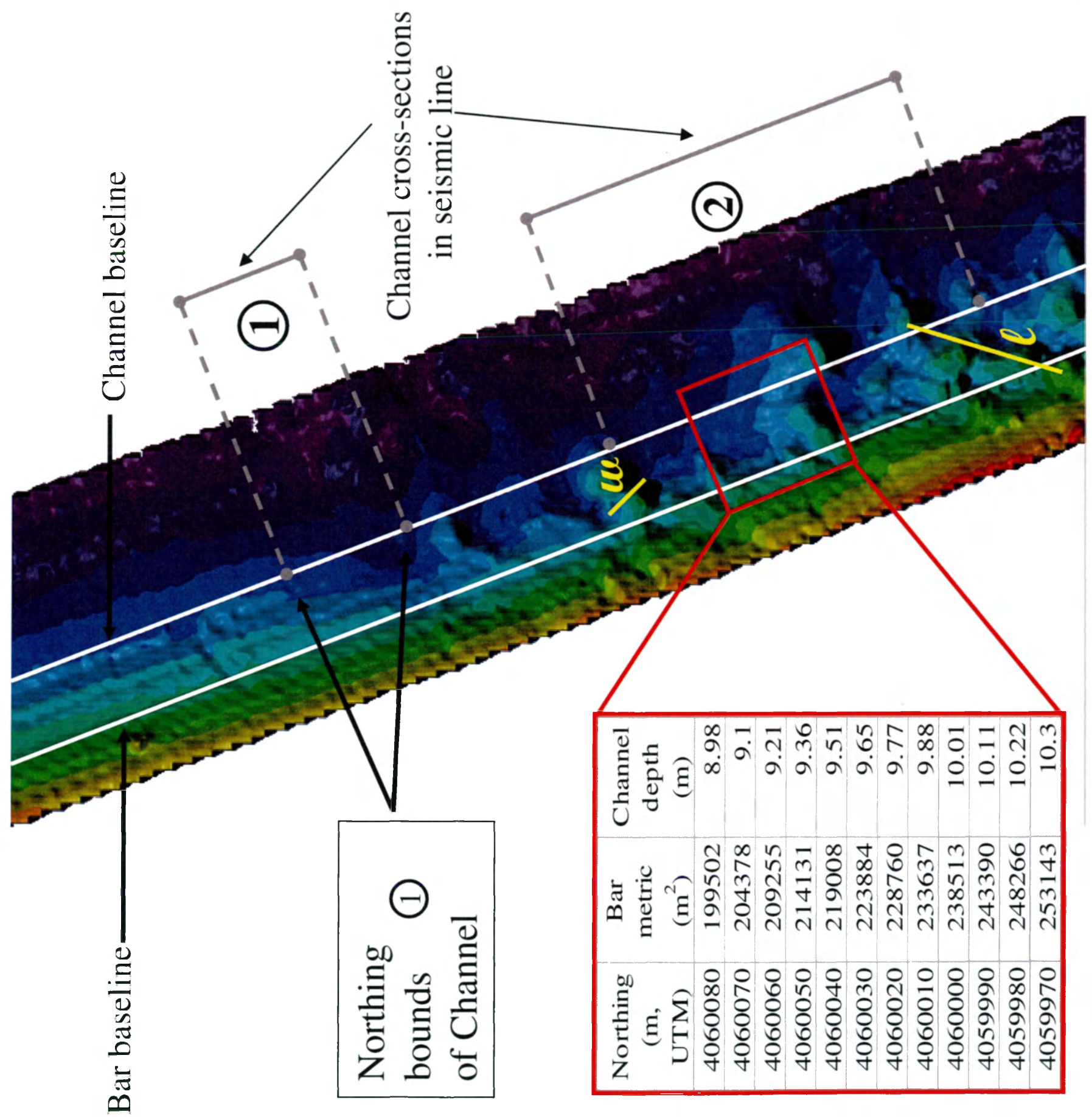


Figure 10

Chirp seismic image showing digitized channel and method of measuring channel parameters. $\mathrm{DBSF}=$ Depth below seafloor. 


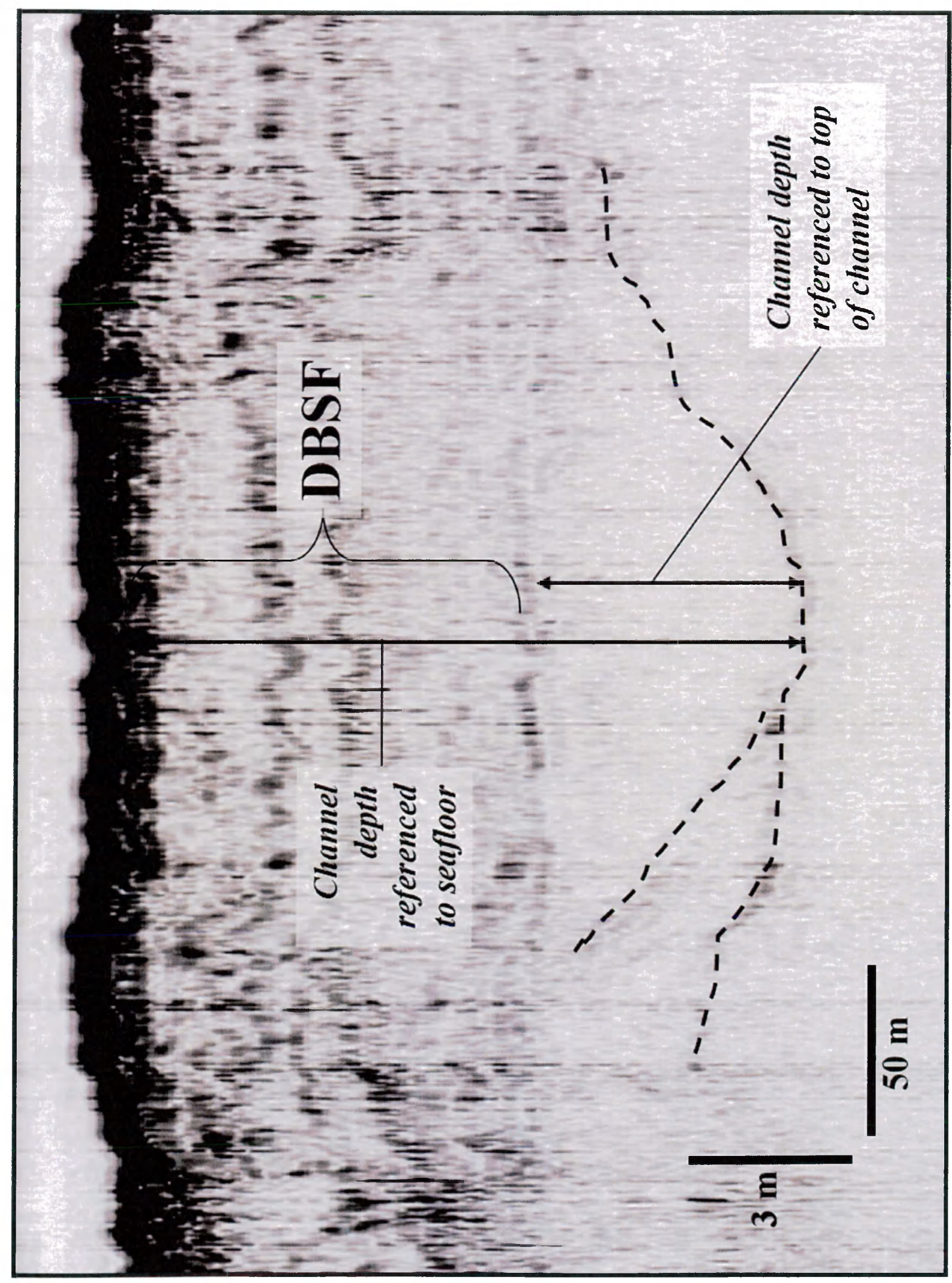


Figure 11

3-D images of a) Sandbridge, VA bar field, b) Kitty Hawk, NC bar field and c) Nags Head, NC bar field. Ellipses highlight bar region. (Images are highly vertically exaggerated.) 


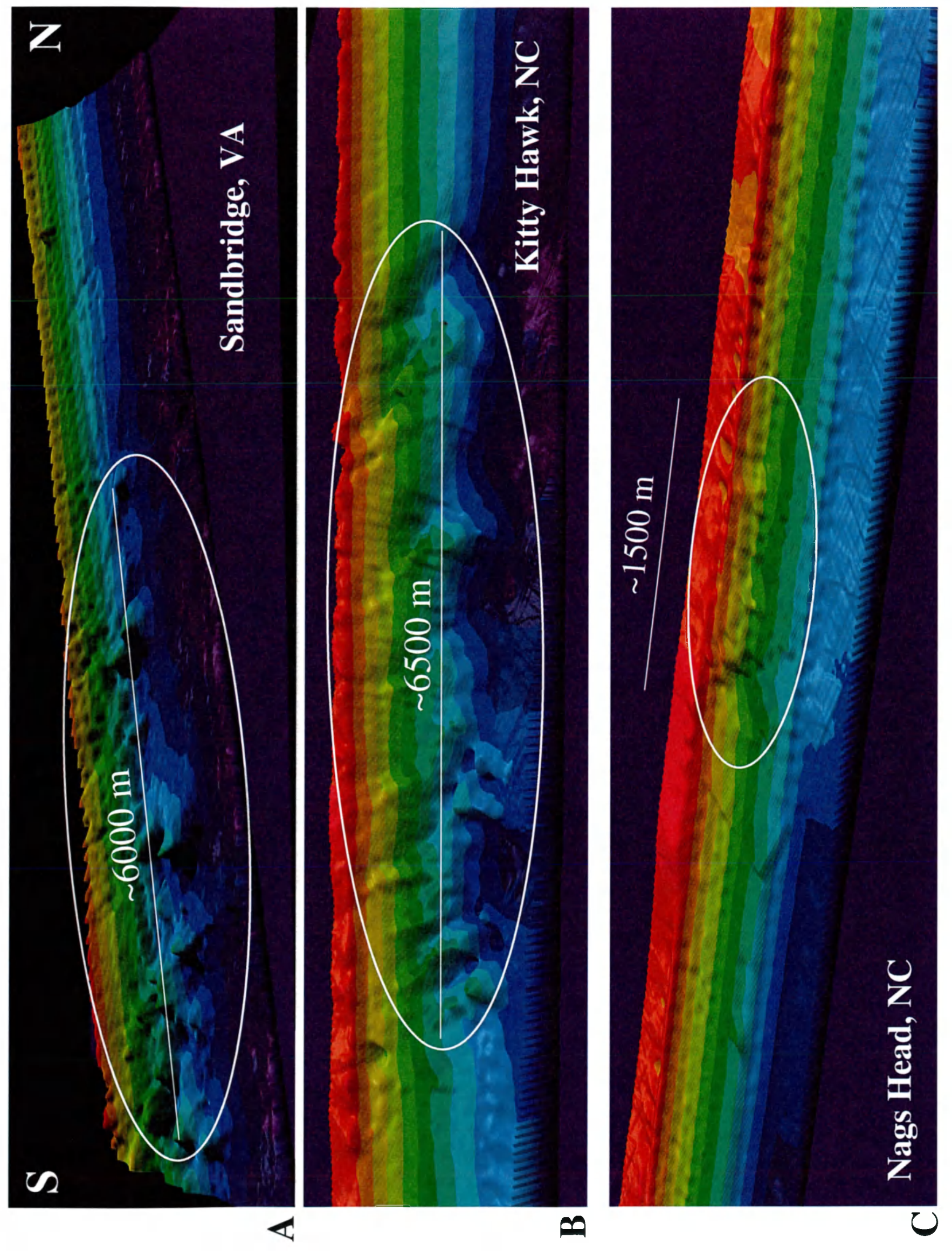


Figure 12

Representative side-scan images from A) a Sandbridge, VA gravel outcrop and B) a Kitty Hawk, NC gravel outcrop. 


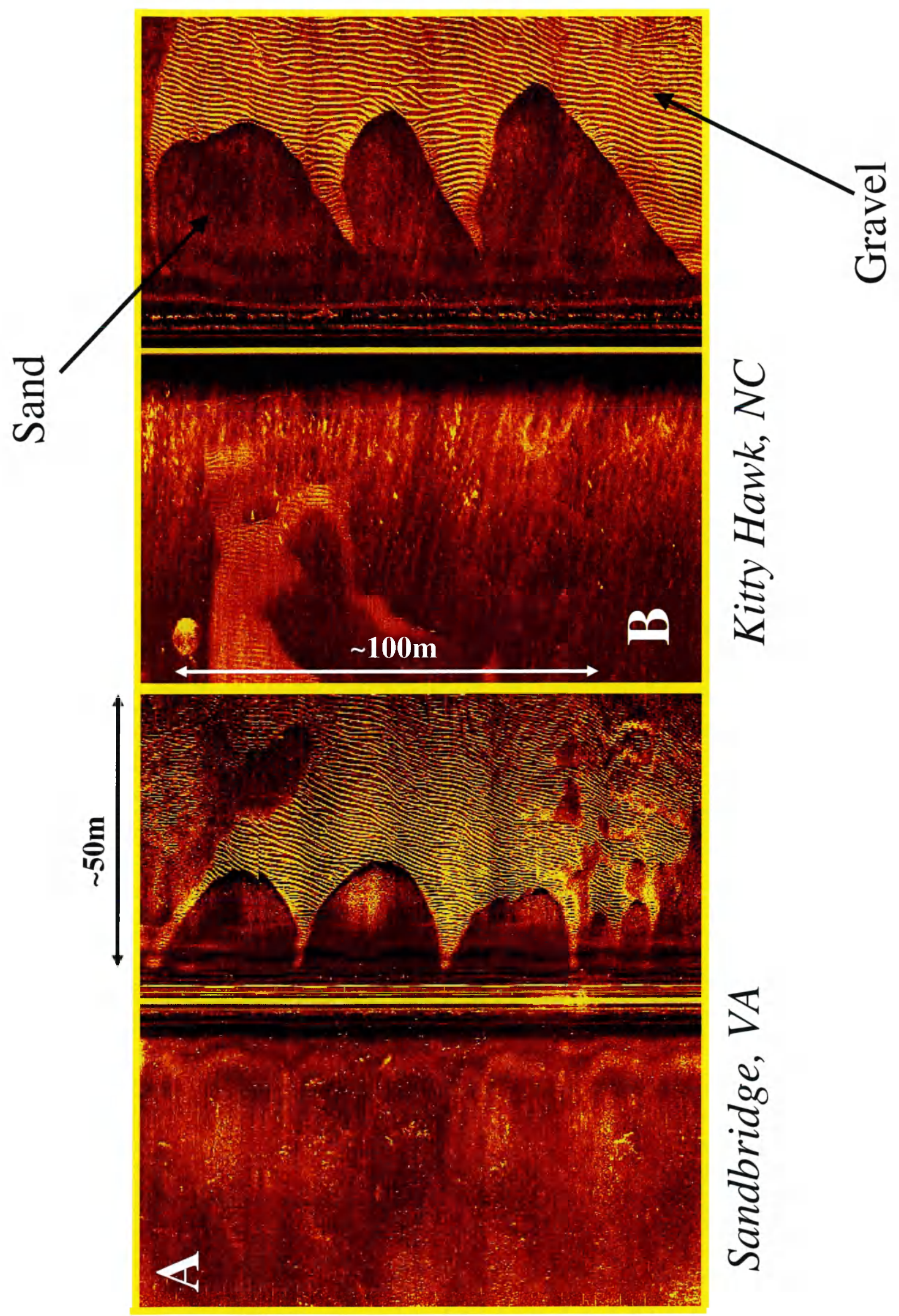


Figure 13

Representative side-scan image from Nags Head, NC. Yellow indicates higher backscatter, and thus coarser sediment. 


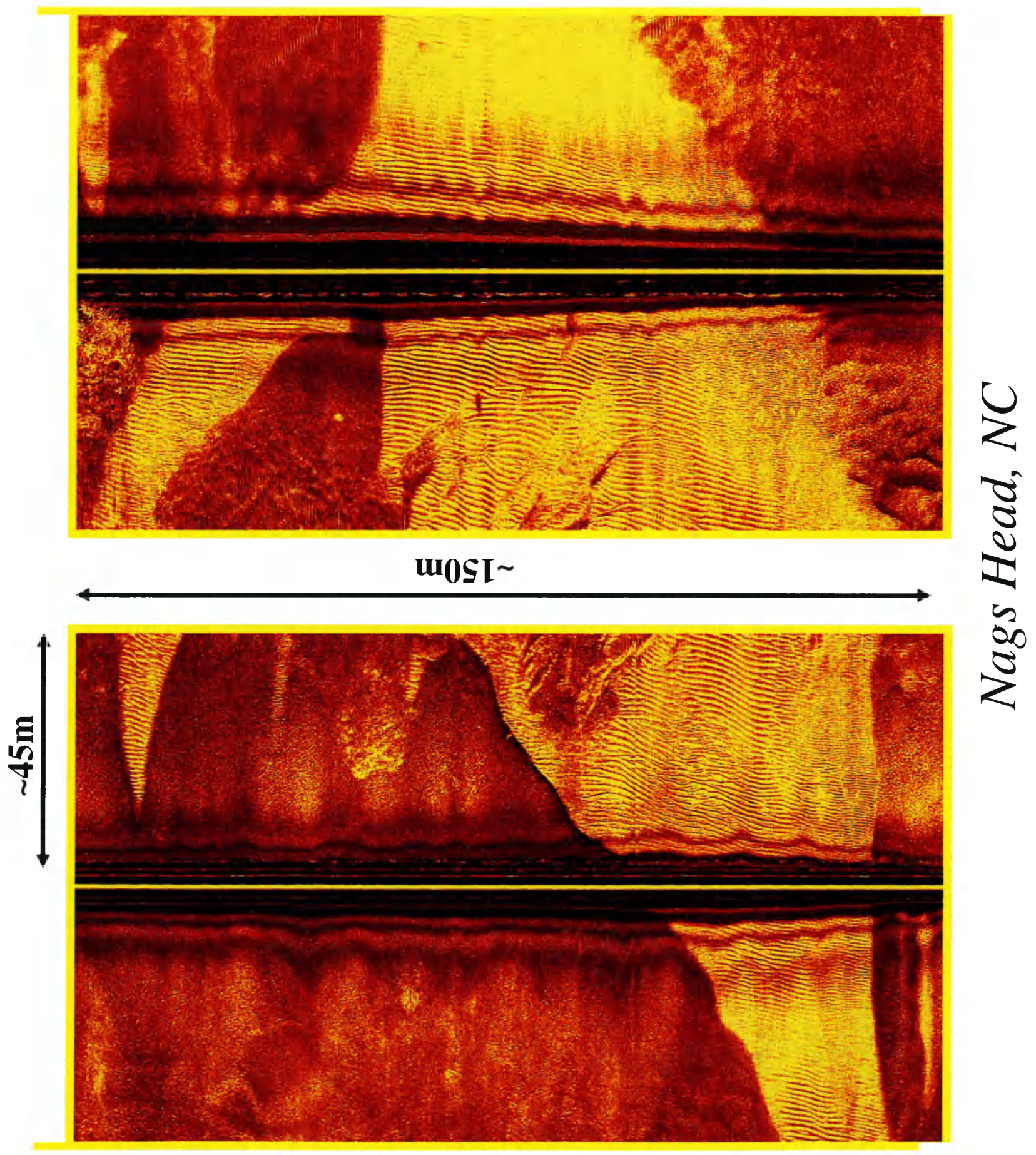




\section{Figure 14}

Representative relict channel cross-sections from the Sandbridge, VA sub-bottom record. Top panel shows data collected along the $5 \mathrm{~m}$ isobath and bottom panel shows the same channel captured at the $7 \mathrm{~m}$ isobath. 


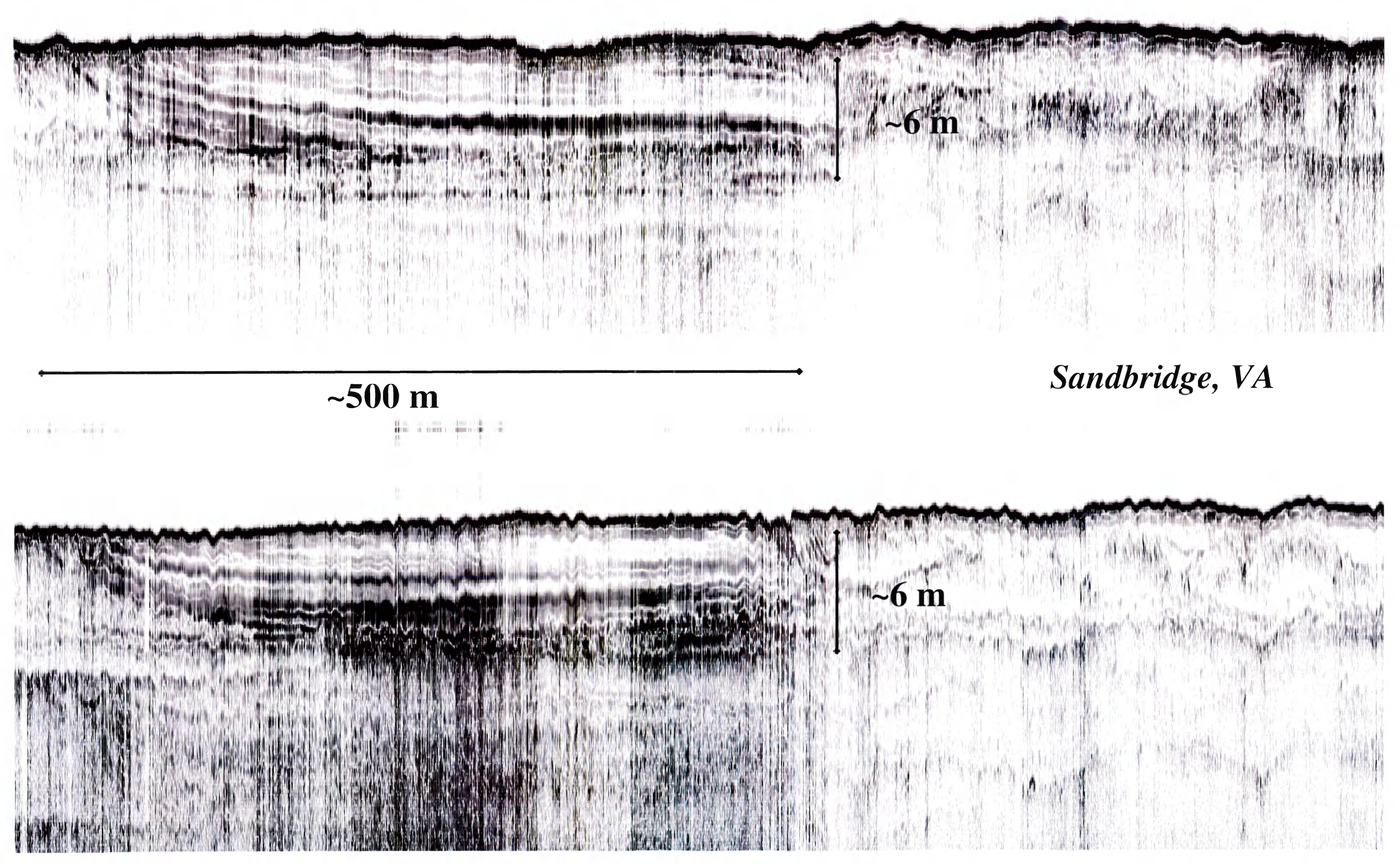


Figure 15

Relict channel cross-section from the Kitty Hawk, NC sub-bottom record collected in $15 \mathrm{~m}$ of water. 


\section{$\sim 6.5 \mathrm{~km}$}

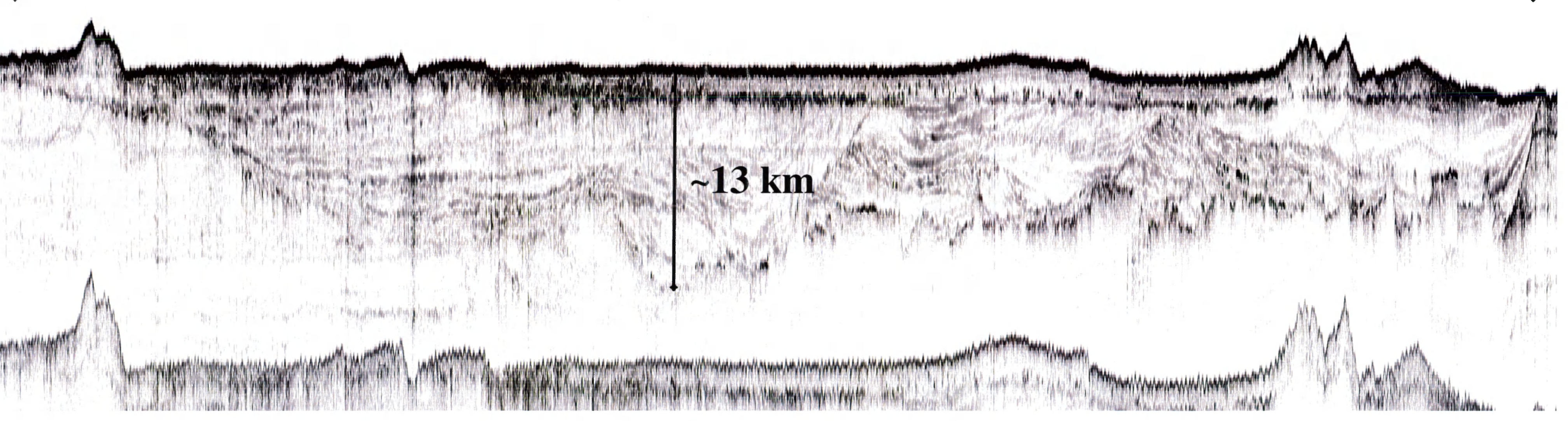

Kitty Hawk, NC 


\section{Figure 16}

Representative relict channel cross-sections from the Nags Head, NC sub-bottom record. Top panel shows data collected along the $12 \mathrm{~m}$ isobath and bottom panel shows the same area of chaotic reflectors recorded at the $15 \mathrm{~m}$ isobath. 


\section{Figure 17}

Sandbridge, VA bathymetry data overlain with gravel outcrop locations (white squares) and channel boundaries (dotted lines). Wider channels (presumed to be fluvial) are colored yellow, while narrow (presumably tidal inlet) channels are colored red. 


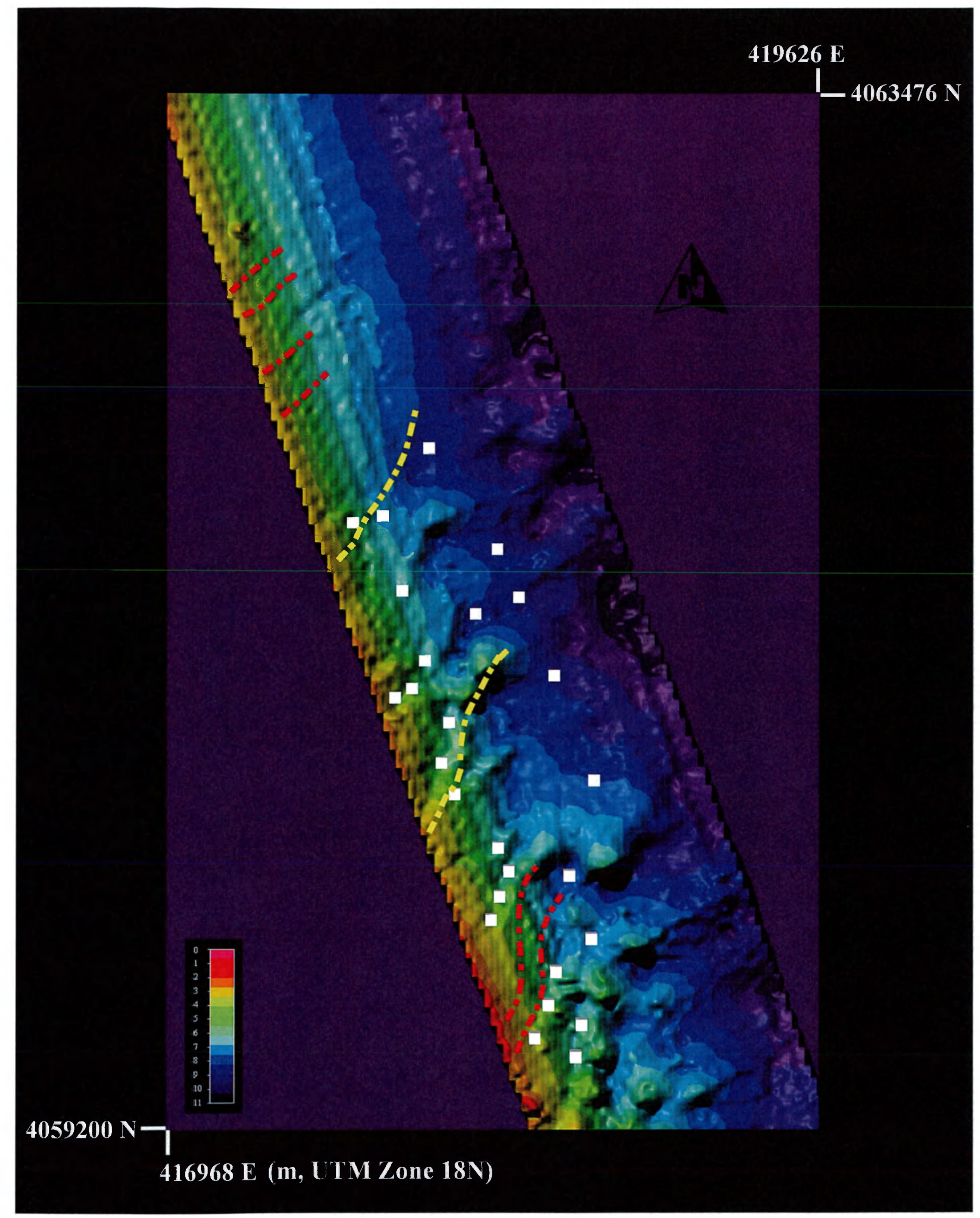




\section{Figure 18}

Kitty Hawk, NC bathymetry data overlain with gravel outcrop locations (white squares) and channel boundaries (dotted lines). 


\section{E}

L_3999520 N

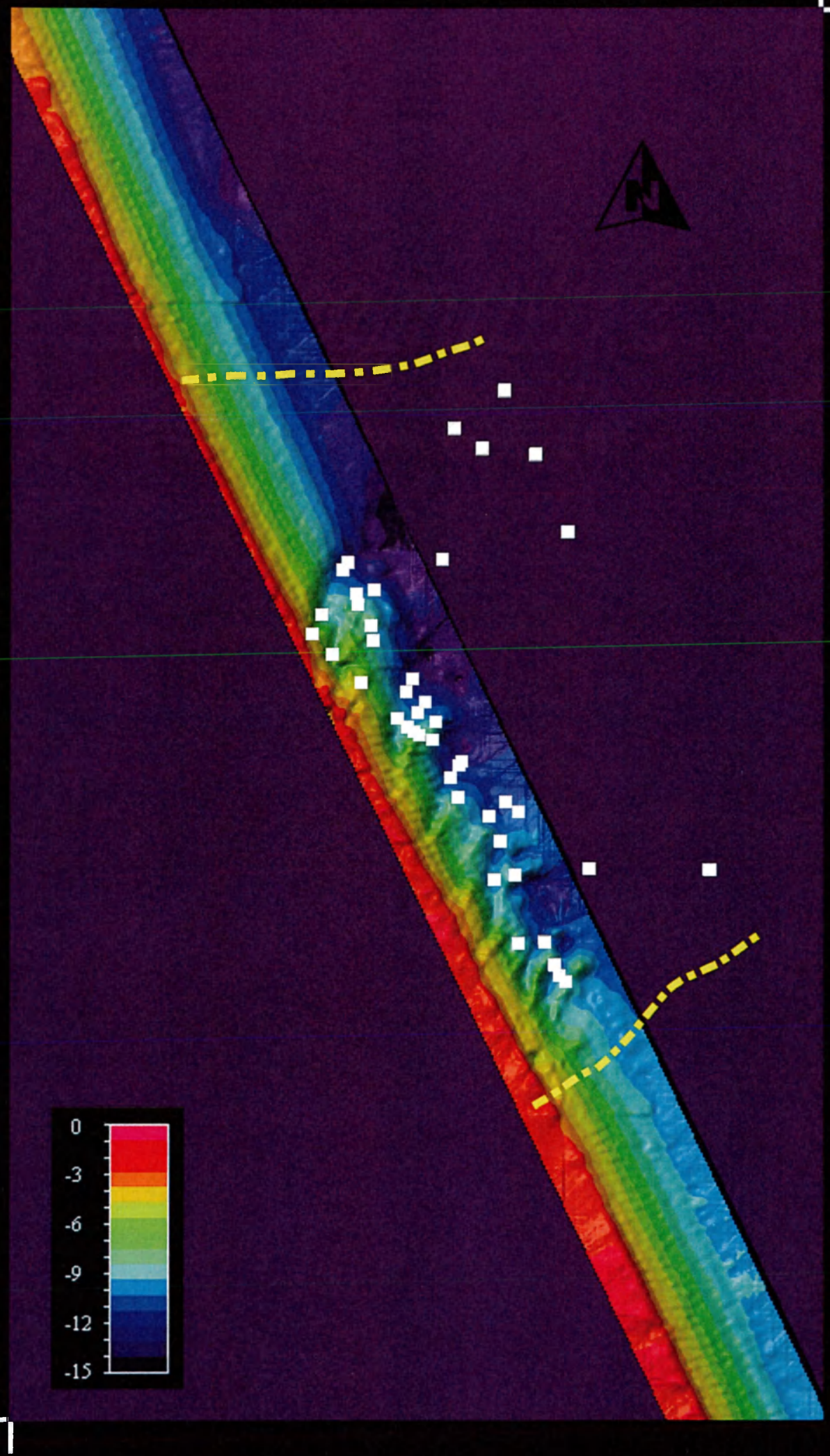

$3983898 \mathrm{~N}-$

434375 E (m, UTM Zone 18N) 


\section{Figure 19}

Nags Head, NC bathymetry data overlain with gravel outcrop locations (white squares) and channel boundaries (dotted lines). Wider channels (presumed to be fluvial) are colored yellow, while narrow (presumably tidal inlet) channels are colored red. 


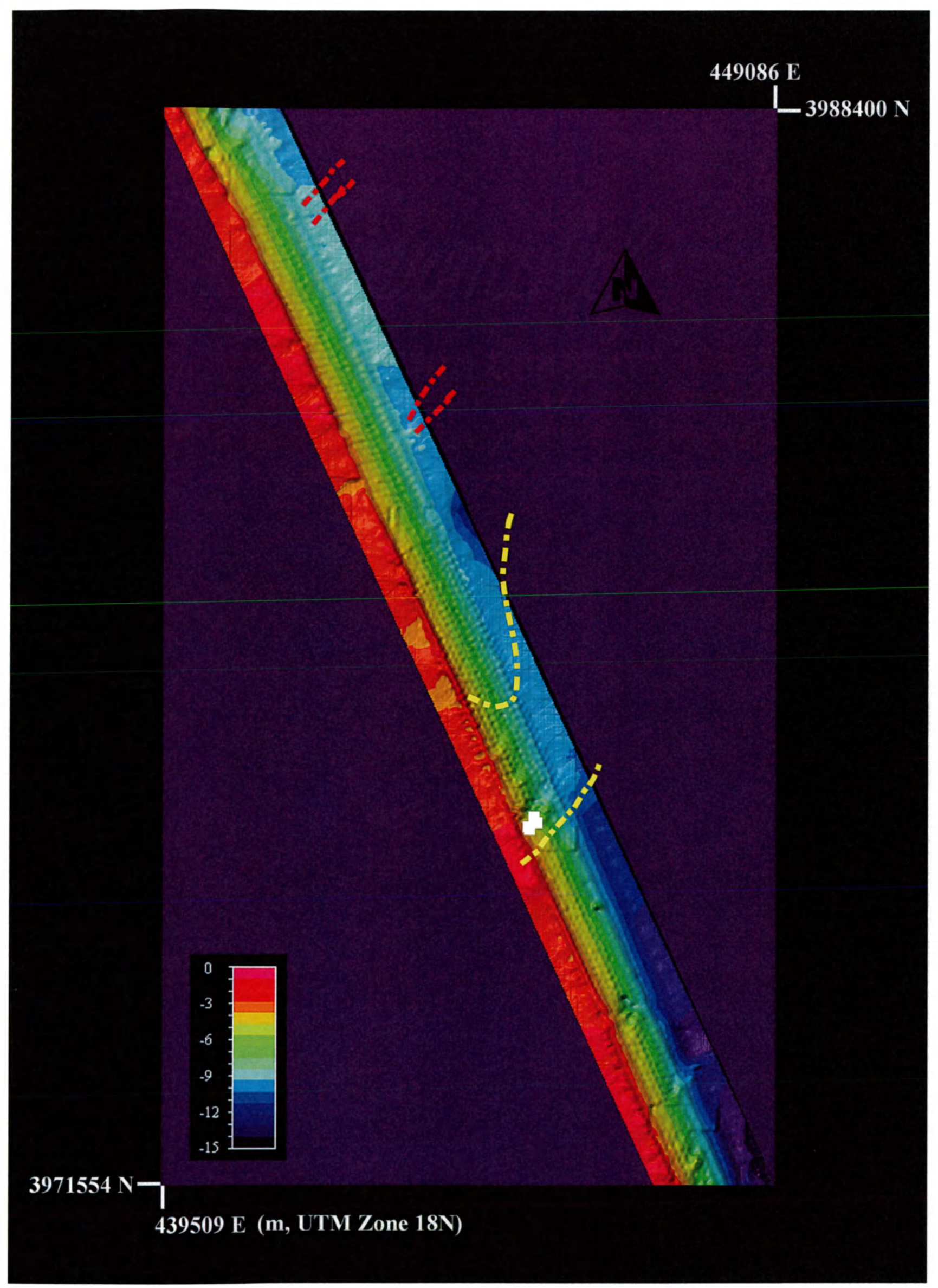




\section{Figure 20}

Sandbridge sub-bottom cross-sections. A-A' lies outside the bar area and exhibits gently sloping reflectors. B-B' falls within the bar area and shows chaotic and truncated reflectors, evidence of channel meandering and downcutting. Cross-section locations are shown in Figure 5. 

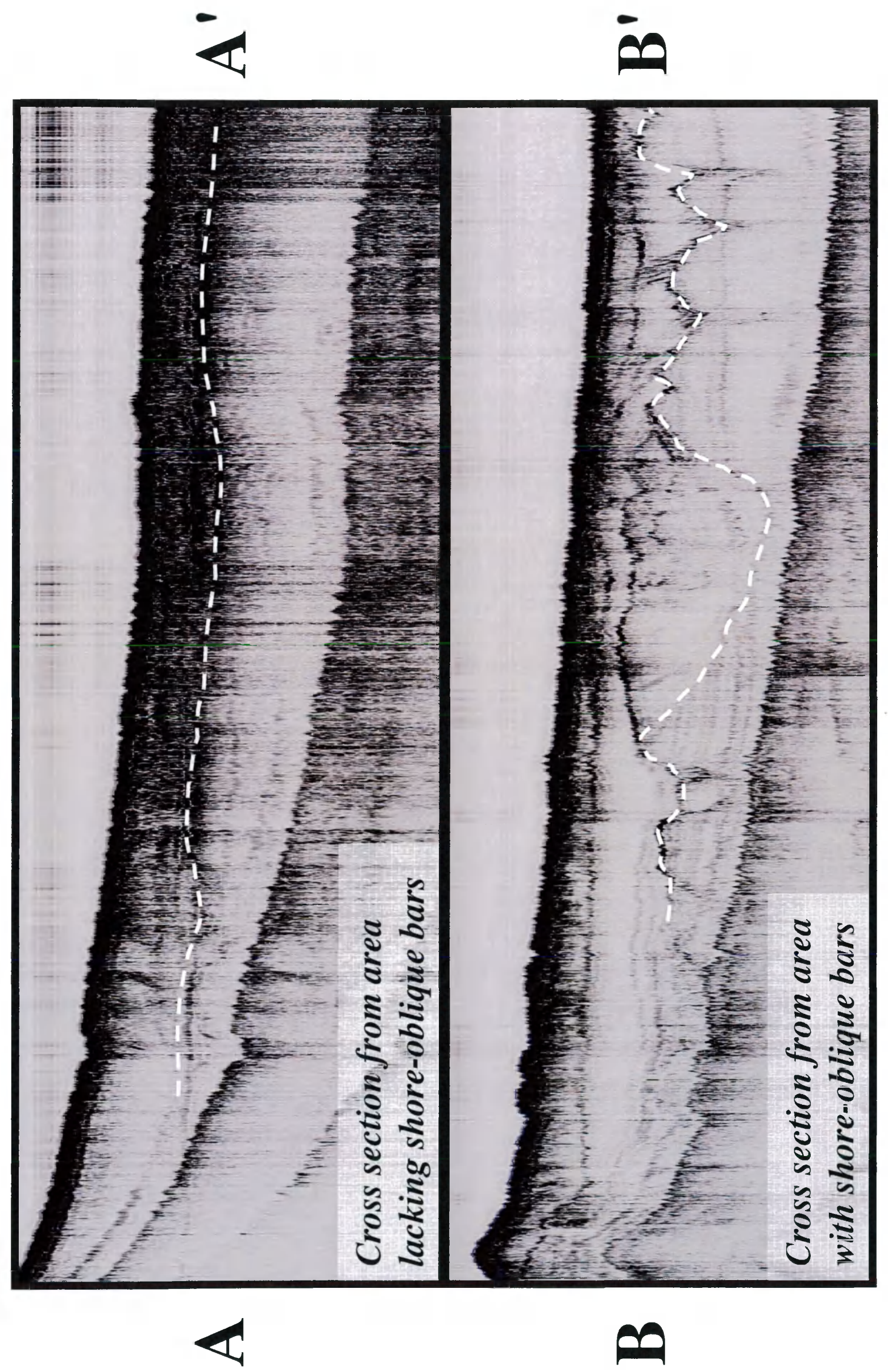
Figure 21

Kitty Hawk sub-bottom cross-sections. As in Sandbridge (Figure 10), only those crosssections underlying the bar area show evidence of buried paleo-channels. Cross-section location is shown in Figure 6. 

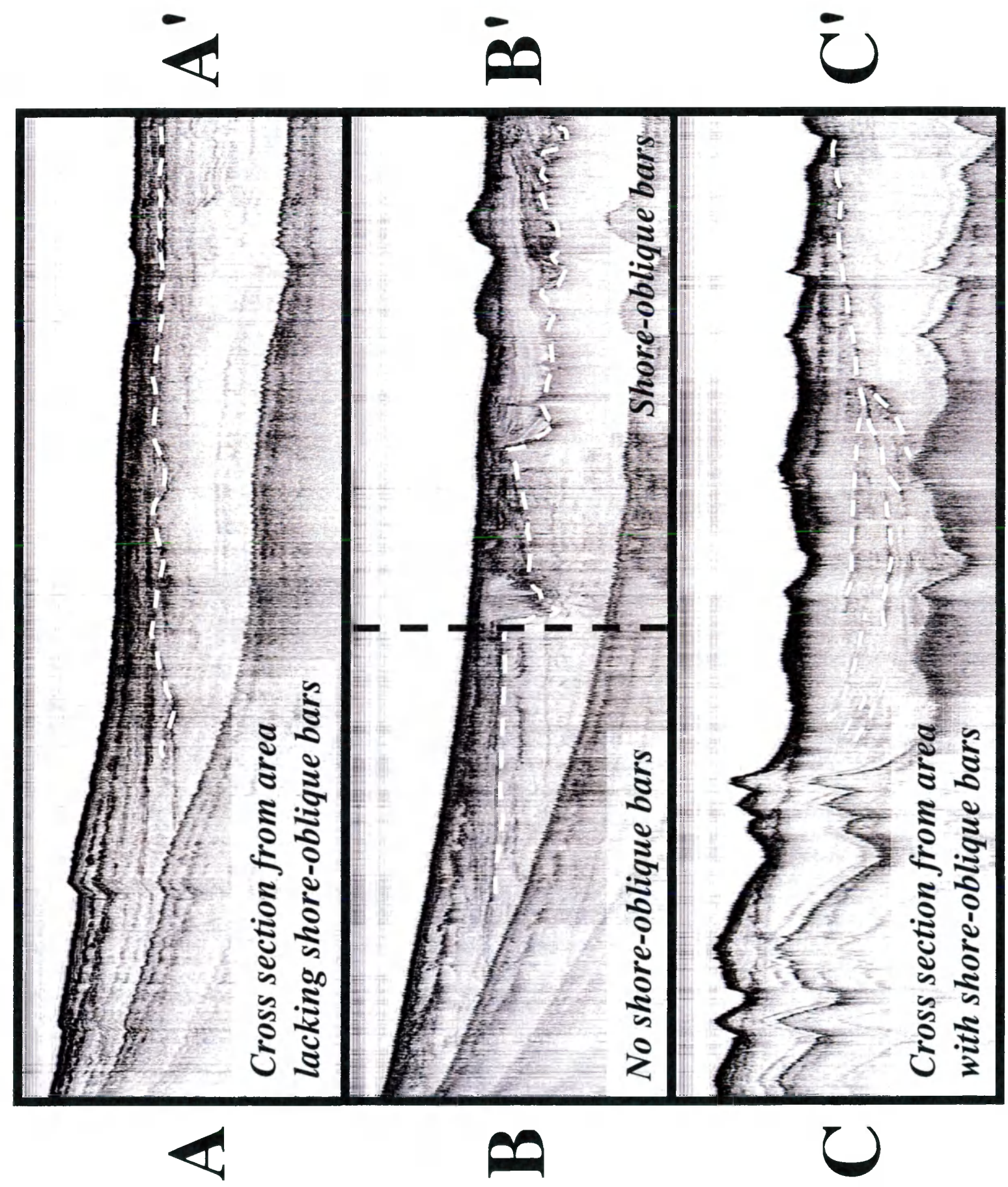
Figure 22

Nags Head sub-bottom cross-sections. Neither line falls near the shore-oblique bar/gravel outcrop region and neither line reveals relict channels. Cross-section locations are shown in Figure 7. 

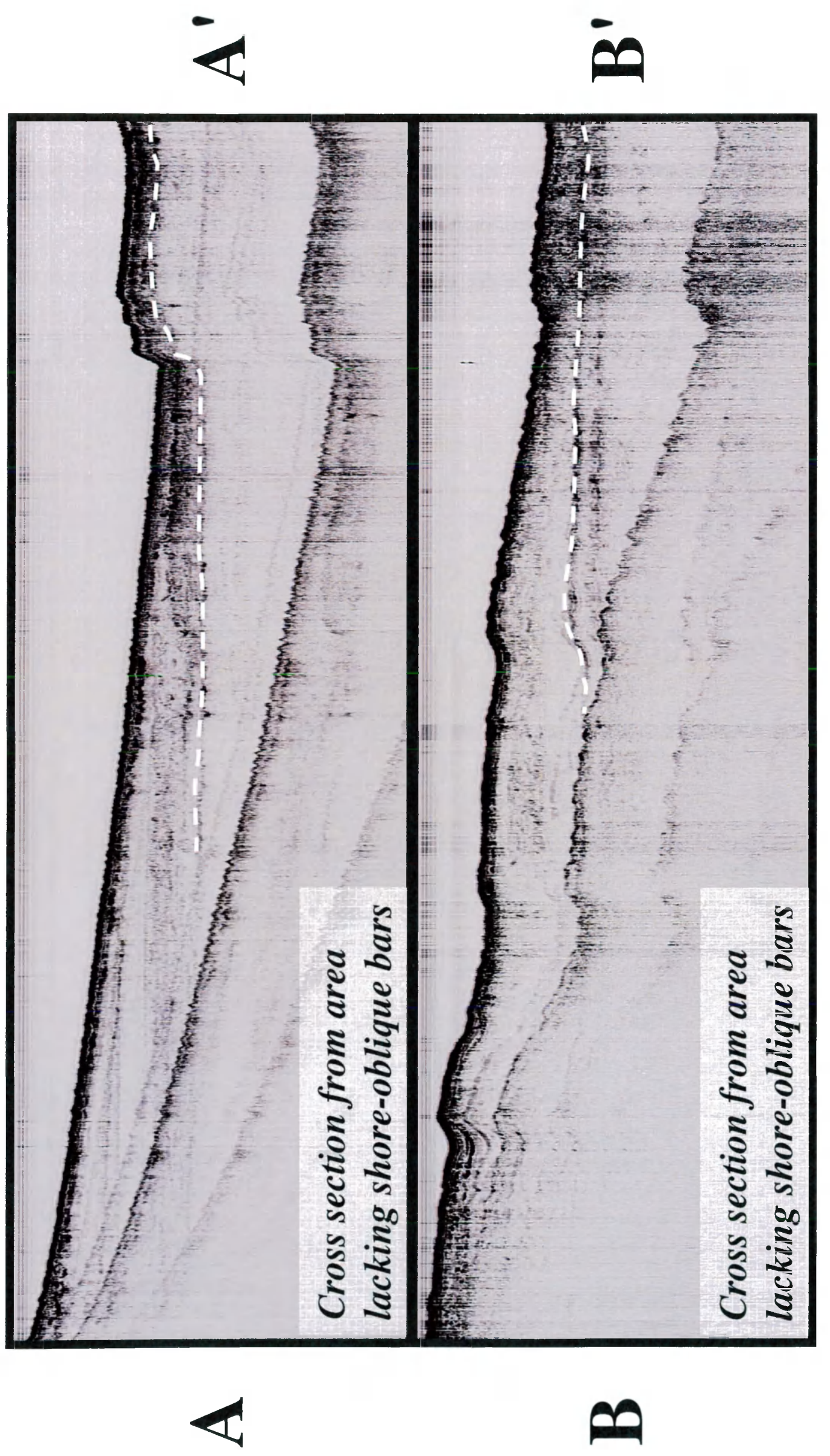
Figure 23

Graph of paleo-channel depths and bar metrics plotted against location (northing, UTM) every 10 meters in the alongshore direction. 
8

Bar metric $\left(\mathbf{m}^{2}\right)$

\begin{tabular}{l}
8 \\
8 \\
0 \\
\hline
\end{tabular}

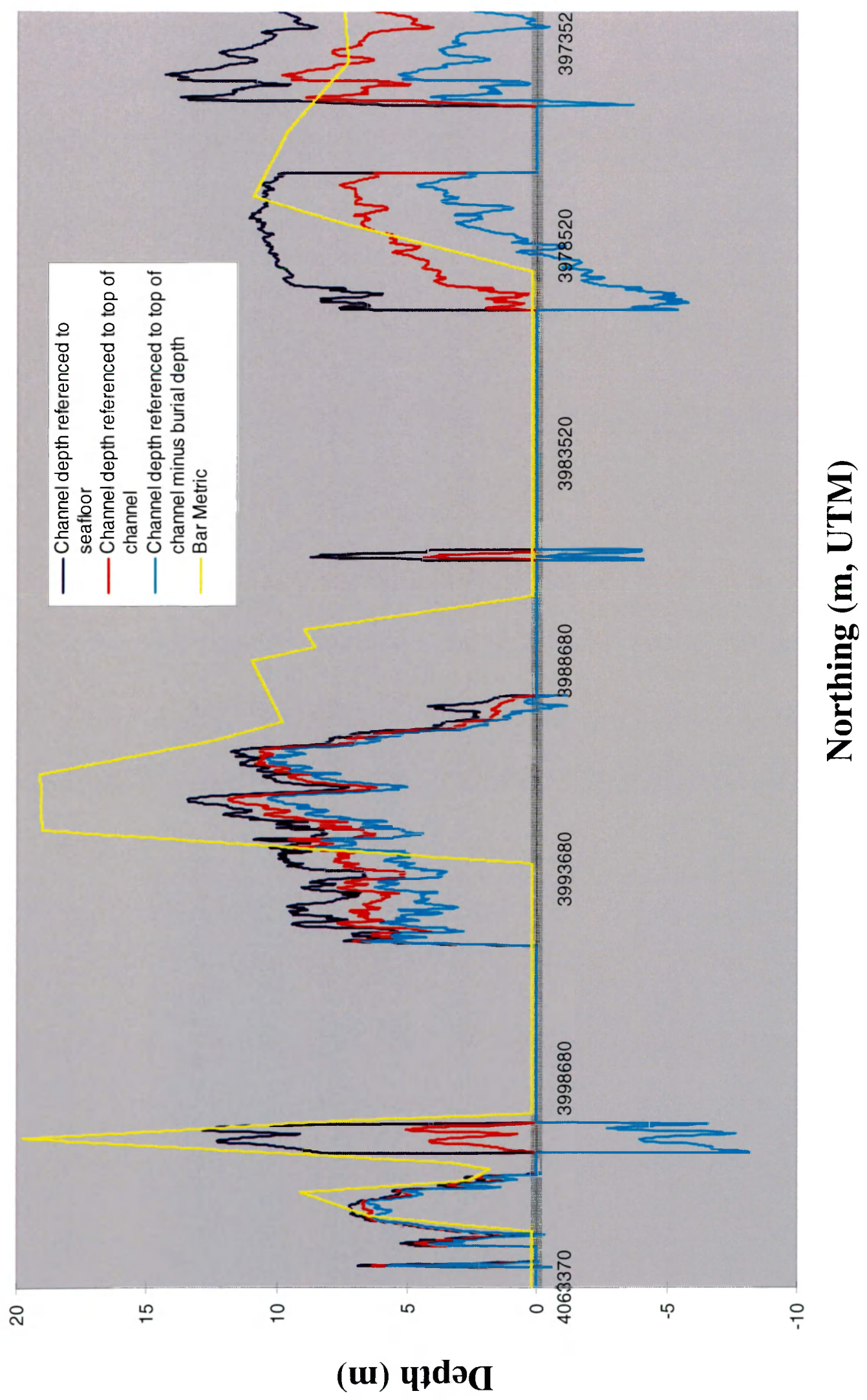




\section{Figure 24}

Cross-correlation analysis results for the Sandbridge, VA site. Green line represents a random comparison, blue line represents a perfect correlation and the pink dotted line represents the actual results of the analysis in question. $\mathrm{Cc}=$ correlation coefficient. 


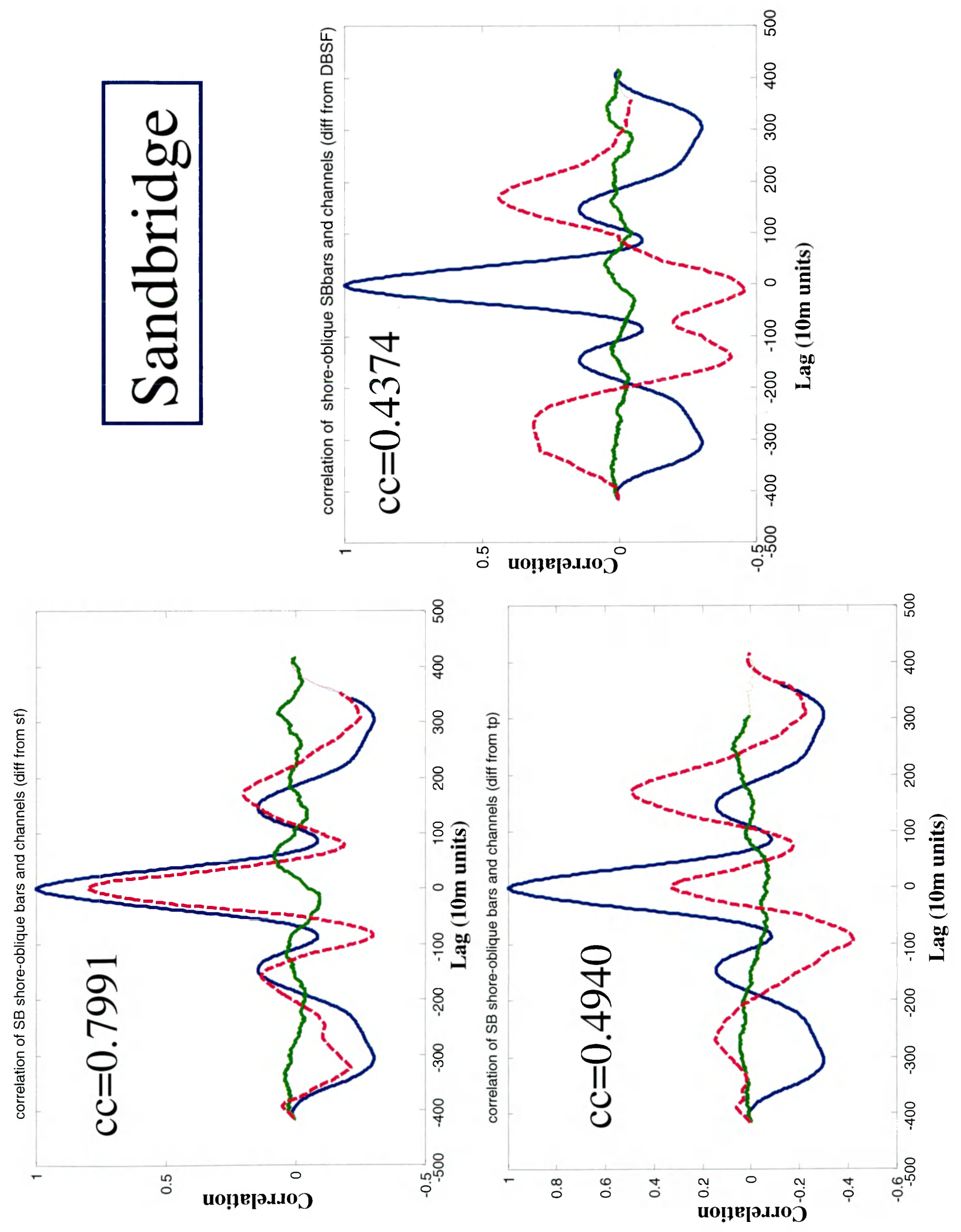


Figure 25

Cross-correlation analysis results for the Kitty Hawk, NC site. Green line represents a random comparison, blue line represents a perfect correlation and the pink dotted line represents the actual results of the analysis in question. $\mathrm{Cc}=$ correlation coefficient. 


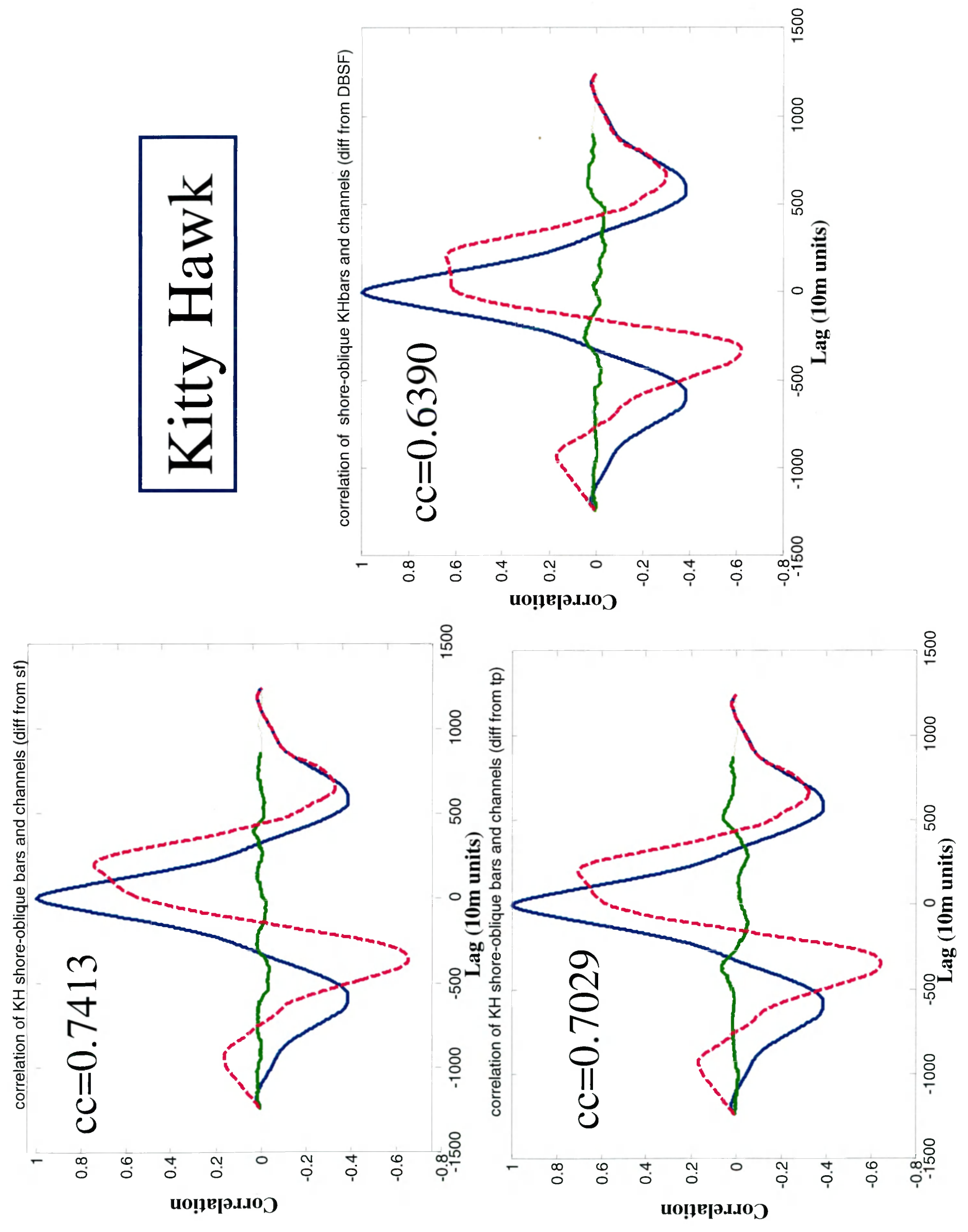


Figure 26

Cross-correlation analysis results for the Nags Head, NC site. Green line represents a random comparison, blue line represents a perfect correlation and the pink dotted line represents the actual results of the analysis in question. $\mathrm{Cc}=$ correlation coefficient. 


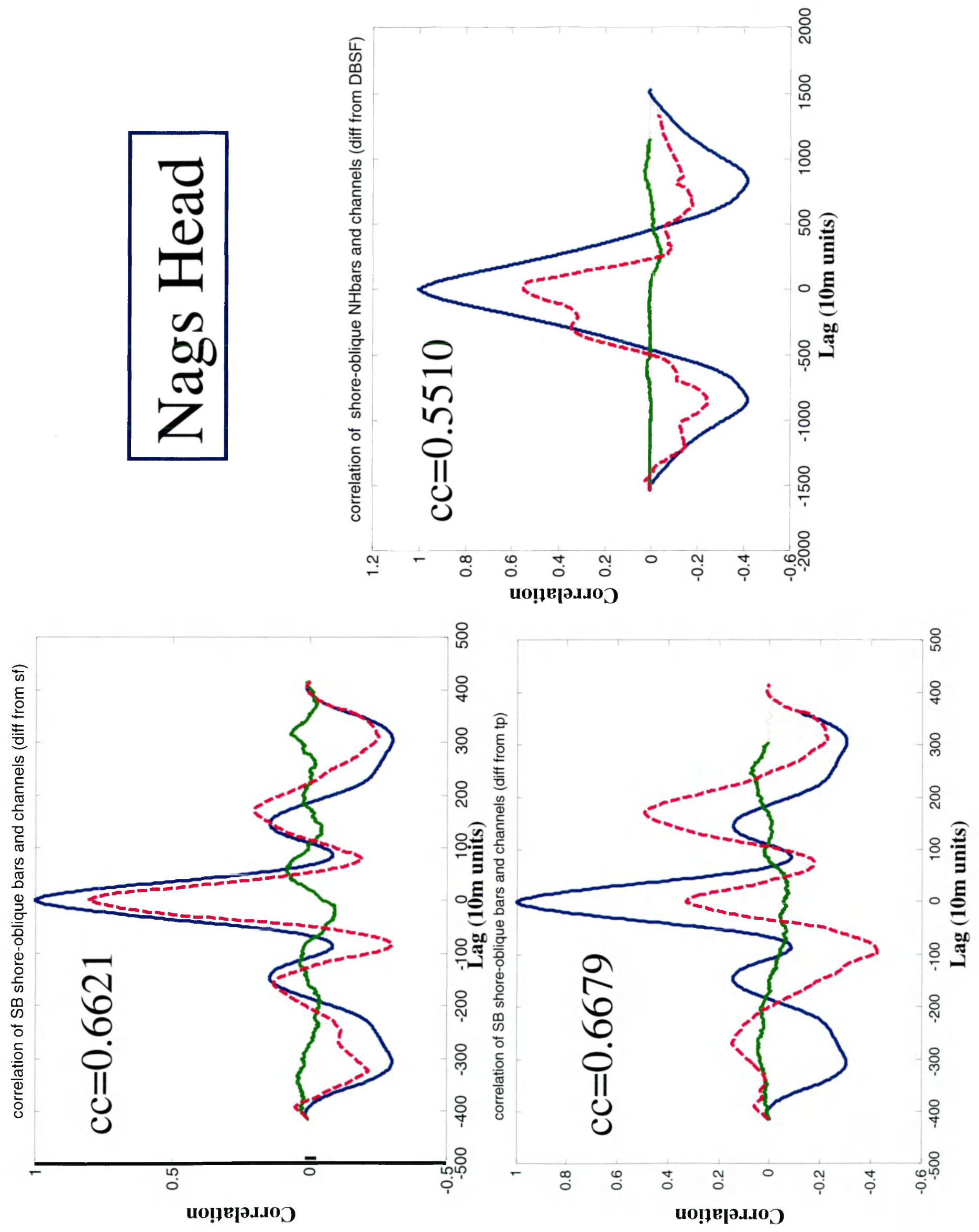




\section{Figure 27}

Cross-correlation analysis results for all sites (analyzed together). Green line represents a random comparison, blue line represents a perfect correlation and the pink dotted line represents the actual results of the analysis in question. $\mathrm{Cc}=$ correlation coefficient. 


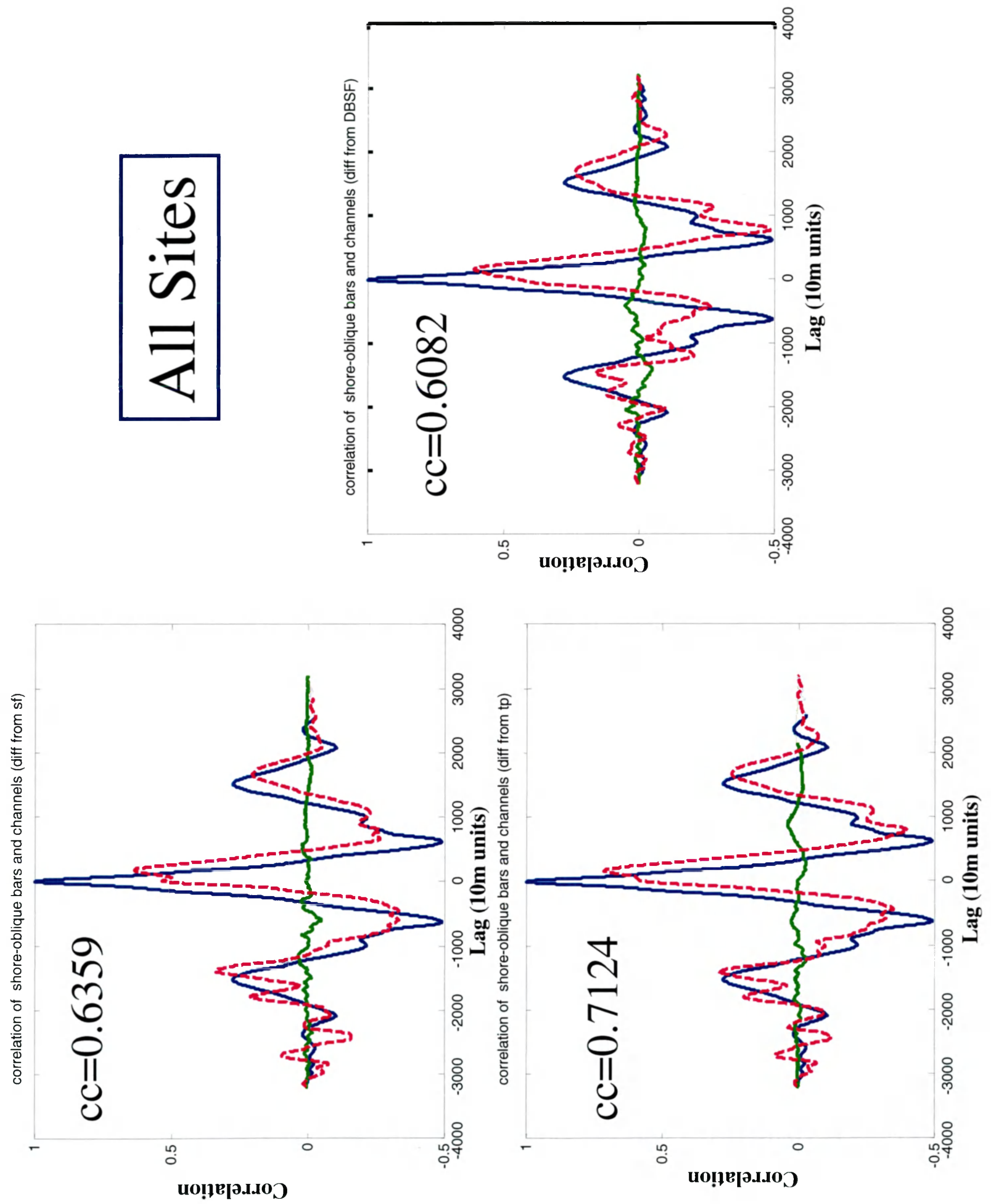


Figure 28

Locations of relict channels in Onslow Bay identifiable in the seismic record at the $10 \mathrm{~m}$ isobath (from Hine and Snyder, 1985) and superposition of 1998 shoreline change rates (from NC Division of Coastal Management). Shaded areas show where elevated erosion rates shown on the graph correspond with the shoreline. 


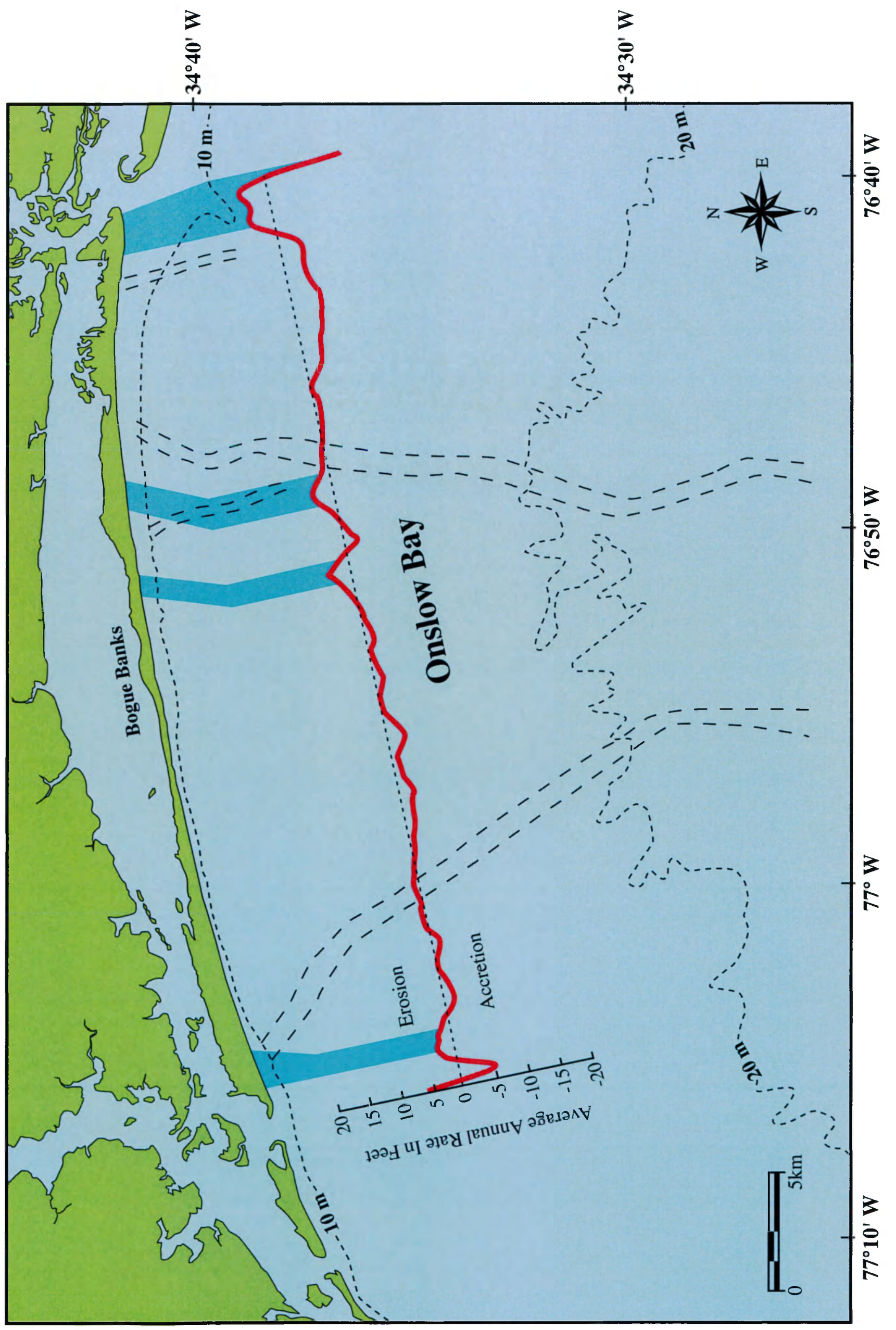




\section{LITERATURE CITED}

Ardhuin, F., O'Reilly, W.C., Herbers, T.H.C. and Jessen, P.F., 2003. Swell transformation across the continental shelf. Part I: Attenuation and directional broadening. J. Phys. Oceanogr., 33: 1921-1939.

Ashton, A., List, J.H., Murray, A.B. and Farris, A.S., 2003. Links between erosional hotspots and alongshore sediment transport, Coastal Sediments, '03. ASCE, St. Petersburg, FL.

Belknap, D.F. and Kraft, J.C., 1981. Preservation potential of transgressive coastal lithosomes on the U.S. Atlantic shelf. Mar. Geol., 42: 429-442.

Belknap, D.F. and Kraft, J.C., 1985. Influence of antecedent geology on stratigraphic preservation potential and evolution of Delaware's barrier systems. Mar. Geol., 63: 235-262.

Bender, C.J. and Dean, R.G., 2003. Wave field modification by bathymetric anomalies and resulting shoreline changes: a review with recent results. Coastal Engineering, 49: 125-153.

Benton, S.B., Bellis, C.J., Overton, M.F., Fisher, J.S., Hench, J.L. and Dolan, R.D., 1997. North Carolina long-term average annual rates of shoreline change, Prepared for Division of Coastal Management, North Carolina Department of Environment, Health, and Natural Resources, Raleigh, NC.

Birkemeier, W.A., Miller, H.C., Wilhelm, S.D., DeWall, A.E. and Gorbics, C.S., 1985. A user's guide to the Coastal Engineering Research Centers (CERC's) field research facility, Coastal Engineering Research Center, United States Army Corps of Engineers, Vicksburg, MS.

Boss, S.K., Hoffman, C.W. and Cooper, B., 2002. Influence of fluvial processes on the Quaternary geologic framework of the continental shelf, North Carolina, USA. Mar. Geol., 183: 45-65.

Bruun, P., 1954. Coastal erosion and development of beach profiles, USACE-WES, Vicksburg, MS.

Cacchione, D.A., Grant, W.D. and Tate, G.B., 1984. Rippled scour depressions on the inner continental shelf off central California. J. Sediment. Petrol., 54: 1280-1291.

Chen, Z.-Q., 1992. An investigation of the late Pleistocene paleochannel systems in the continental shelf, south of Chesapeake Bay mouth. Master's Thesis, Virginia Institute of Marine Science, College of William and Mary, Gloucester Point, VA.

Chen, Z.-Q., Hobbs, C.H., III, Wehmiller, J.F. and Kimball, S.M., 1995. Late Quaternary paleochannel systems on the continental shelf, south of the Chesapeake Bay entrance. J. Coast. Res., 11(3): 605-614.

Colman, S.M., Halka, J.P., Hobbs, C.H., III, Mixon, R.B. and Foster, D.S., 1990. Ancient channels of the Susquehanna River beneath Chesapeake Bay and the Delmarva Peninsula. Geological Society of America Bulletin, 102: 1268-1279.

Corbett, D.R., Burnett, W.C. and Chanton, J.P., 2001. Submarine groundwater discharge: An unseen yet potentially important coastal phenomenon, Sea Grant Florida, SGEB-54. 
Cox, M.O., III, Howd, P.A. and Kirby, J.T., 1995. Application of a weakly non-linear wave refraction/diffraction model to the Wimble Shoals, NC region. Eos Transactions, 76(46): 297.

Dame, J.K., 1990. Origin of a solitary sand shoal offshore of Sandbridge Beach, Virginia. Master's Thesis, Virginia Institute of Marine Science, The College of William and Mary, Gloucester Point, VA.

Davis, J.C., 1983. Statistics and Data Analysis in Geology. John Wiley \& Sons, New York, $646 \mathrm{pp}$.

Dean, R.G., 1991. Equilibrium beach profiles: characteristics and applications. J. Coast. Res., 7(1): 53-84.

Dean, R.G., Liotta, R. and Simon, G., 1999. Erosional Hot Spots. Prepared for: FL Dept of Environmental Protection, Office of Beaches and Coastal Systems.

Demarest, J.M. and Leatherman, S.P., 1985. Mainland influence on coastal transgression: Delmarva peninsula. Mar. Geol., 63: 19-33.

Duane, D.B., Field, M.E., Meisburger, E.P., Swift, D.J.P. and Williams, S.J., 1972. Linear shoals on the Atlantic inner continental shelf, Florida to Long Island. In: D.J.P. Swift, D.B. Duane and O.H. Pilkey (Editors), Shelf Sediment Transport: Process and Pattern. Dowden, Hutchinson \& Ross, Inc., Stroudsburg, Pennsylvania.

Evans, D.A., Fundamentals of Statistical Methods and Data Analysis, MS504, Virginia Institute of Marine Science, Gloucester Point, VA, Fall 2002

Fairbanks, R.G., 1989. A 17,000-year glacio-eustatic sea level record: influence of glacial melting rates on the Younger Dryas event and deep-ocean circulation. Nature, 342: 637-642.

Fenster, M.S. and Dolan, R., 1993. Historical shoreline trends along the Outer Banks, North Carolina: Processes and responses. J. Coast. Res., 9(1): 172-188.

Fenster, M.S. and Dolan, R., 1996. Assessing the impact of tidal inlets on adjacent barrier island shorelines. Journal of Coastal Research, 12(1): 294-310.

Fisher, J.J., 1962. Geomorphic expression of former inlets along the outer banks of North Carolina, University of North Carolina, $119 \mathrm{pp}$.

Gayes, P.T., 1998. Regionally linking the active beach across the shoreface and inner shelf: the SC coastal erosion program, Geological Society of America Abstracts with Programs, pp. 109.

Green, M.O., Vincent, C.E. and Trembanis, A.C., 2004. Suspension of coarse and fine sand on a wave-dominated shoreface, with implications for the developments of rippled scour depressions. Cont. Shelf Res., 24: 317-335.

Gutierrez, B.T., Voulgaris, G. and Thieler, E.R., 2005. Exploring the persistence of sorted bedforms on the inner-shelf of Wrightsville Beach, North Carolina. Cont. Shelf Res., 25: 65-90.

Harrison, W., Malloy, R.J., Rusnak, G.A. and Terasmae, J., 1965. Possible late Pleistocene uplift Chesapeake Bay entrance. The Journal of Geology, 73(2): 201229.

Hayes, M.O., 1979. Barrier island morphology as a function of tidal and wave regime. In: S.P. Leatherman (Editor), Barrier islands from the Gulf of St. Lawrence to the Gulf of Mexico. Academic Press, New York, NY. 
Hine, A.C. and Snyder, S.W., 1985. Coastal lithosome preservation: Evidence from the shoreface and inner continental shelf off Bogue Banks, North Carolina. Mar. Geol., 63: 307-330.

Hobbs, C.H., III, 1990. Acoustic geology of a portion of Virginia's innermost continental shelf. In: VA Division of Mineral Resources Publication 103: Heavy-mineral studies--VA inner continental shelf, C.R. Berquist, Jr., Editor.

Hobbs, C.H., III, 1997. Sediments and shallow stratigraphy of a portion of the continental shelf of southeastern Virginia. Cooperative Agreement 14-35-0001-30740, Contract Report for U.S. Department of the Interior Minerals Management Service.

Hobbs, C.H., III, 2004. Geological history of Chesapeake Bay, USA. Quaternary Science Reviews, 23: 641-661.

Hobbs, C.H., III, Milligan, D.A. and Hardaway, C.S., Jr., AF.ASCE, 1999. Long-term trends and short-term variability in shoreline change rates: Southeastern Virginia. Coastal Sediments '99: 1268-1283.

Honeycutt, M.G. and Krantz, D.E., 2003. Influence of the geologic framework on spatial variability in long-term shoreline change, Cape Henlopen to Rehoboth Beach, Delaware. J. Coast. Res., 38: 147-167.

Kimball, S.M. and Dame, J.K., 1989. Geotechnical evaluation of sand resources on the inner shelf of southern Virginia, VIMS.

Komar, P.D., 1998. Beach Processes and Sedimentation. Prentice-Hall, Inc., Upper Saddle River, New Jersey.

Konicki, K.M. and Holman, R.A., 2000. The statistics and kinematics of transverse sand bars on an open coast. Mar. Geol., 169: 69-101.

Kraft, J.C., Chrzastowski, M.J., Belknap, D.F., Toscano, M.A. and Fletcher, C.H., 1987. The transgressive barrier-lagoon coast of Delaware: morphostratigraphy, sedimentary sequences and responses to relative rise in seal-level. In: D. Nummedal, O.H. Pilkey and J.D. Howard (Editors), Sea-level fluctuation and coastal evolution. Society of Economic Paleontologists and Mineralogists, pp. 129-143.

Kraus, N.C. and Galgano, F.A., 2001. Beach erosional hot spots: types, causes, and solutions. Proc. 14th Annual National Conf. on Beach Preservation Technology.

Lippmann, T.C. and Holman, R.A., 1990. The spatial and temporal variability of sand bar morphology. J. Geophys. Res., 95(C7): 11,575-11,590.

List, J.H. and Farris, A.S., 1999. Large-scale shoreline response to storms and fair weather. Coastal Sediments '99: 1324-1338.

Maa, J.P.-Y. and Hobbs, C.H., III, 1998. Physical impact of waves on adjacent coasts resulting from dredging at Sandbridge Shoal, Virginia. J. Coast. Res., 14(2): 525536.

McBride, R.A. and Moslow, T.F., 1991. Origin, evolution, and distribution of shoreface sand ridges, Atlantic inner shelf, U.S.A. Mar. Geol., 97: 57-85.

McNinch, J.E., 2004. Geologic control in the nearshore: shore-oblique sandbars and shoreline erosional hotspots, Mid-Atlantic Bight, USA. Mar. Geol., 211(1-2): 121-141.

McNinch, J.E. and Drake, T.G., 2001. Influences of underlying geology on nearshore and shoreline processes, Geological Society of America, Southeastern Section, 50th 
annual meeting. Abstracts with Programs - Geological Society of America, pp. 32.

McNinch, J.E., Miselis, J.L. and Schupp, C.A., 2002. Linking geologic framework to nearshore processes and shoreline change: results from the Outer Banks of North Carolina, Eos Transactions, American Geophysical Union.

McNinch, J.E., Wells, J.T. and Drake, T.G., 2001. The fate of artifacts in an energetic, shallow-water environment: scour and burial at the wreck site of Queen Anne's Revenge. Southeastern Geology, 40(1): 19-27.

Meisburger, E.P., 1972. Geomorphology and Sediments of the Chesapeake Bay Entrance, U.S. Army, Corps of Engineers Coastal Engineering Research Center.

Miselis, J.L. and McNinch, J.E., 2002. The relationship between shoreline change and surf zone sand thickness, Eos Transactions, American Geophysical Union, San Francisco, CA.

Miselis, J.L. and McNinch, J.E., 2003. Shoreline change and surf zone sand thickness, Assateague Shelf and Shore Conference, George Mason University, Washington, DC.

Mixon, R.B., 1985. Stratigraphic and Geomorphic Framework of Uppermost Cenozoic Deposits in the Southern Delmarva Peninsula, Virginia and Maryland, United States Geological Survey Professional Paper 1067-G.

Moslow, T.F. and Heron, S.D., Jr., 1978. Relict inlets: Preservation and occurrence in the Holocene stratigraphy of southern Core Banks, North Carolina. J. Sediment. Petrol., 48(4): 1275-1286.

Murray, A.B. and Thieler, E.R., 2004. A new hypothesis and exploratory model for the formation of large-scale inner-shelf sediment sorting and "rippled scour depressions". Cont. Shelf Res., 24: 295-315.

Niederoda, A.W. and Tanner, W.F., 1970. Preliminary study of transverse bars. Mar. Geol., 9: 41-62.

Oertel, G.F. and Foyle, A.M., 1995. Drainage displacement by sea-level fluctuation at the outer margin of the Chesapeake seaway. J. Coast. Res., 11(3): 583-604.

O'Reilly, W.C. and Guza, R.T., 1993. A comparison of two spectral wave models in the Southern California Bight. Coastal Engineering, 19: 263-282.

Owens, J.P. and Gohn, G.S., 1985. Depositional history of the Cretaceous series in the U.S. Atlantic Coastal Plain: stratigraphy, paleoenvironments, and tectonic controls of sedimentation. In: C.W. Poag (Editor), Geologic Evolution of the United States Atlantic Margin. Van Nostrand Reinhold Co., New York.

Pearson, D.K., 1979. Surface and shallow subsurface sediment regime of the nearshore inner continental shelf, Nags Head and Wilmington areas, North Carolina, East Carolina University, Greenville, $120 \mathrm{pp}$.

Pilkey, O.H., Young, R.S., Riggs, S.R., Smith, A.W., Wu, H. and Pilkey, W.D., 1993. The concept of shoreface profile of equilibrium: a critical review. J. Coast. Res., 9(1): 255-278.

Rice, T.M., Beavers, R.L. and Snyder, S.W., 1998. Preliminary geologic framework of the inner continental shelf offshore Duck, North Carolina, U.S.A. J. Coast. Res., 26: 219-225.

Riggs, S.R. and Belknap, D.F., 1988. Upper Cenozoic processes and environments of continental margin sedimentation: eastern United States. In: R.E. Sheridan, and 
Grow, J.A. (Editor), The Atlantic Continental Margin, U.S. Geological Society of America, The Geology of North America, pp. 131-176.

Riggs, S.R., Cleary, W.J. and Snyder, S.W., 1995. Influence of inherited geologic framework on barrier shoreface morphology and dynamics. Mar. Geol., 126: 213234.

Riggs, S.R., York, L.L., Wehmiller, J.F. and Snyder, S.W., 1992. Depositional patterns resulting from high-frequency quaternary sea-level fluctuations in northeastern North Carolina. Quaternary Coasts of the United States: Marine and Lucustrine Systems, SEPM Special Publication No. 48.

Roberts, C.S. and Snyder, S.W., 2001. Relationships between shoreline retreat rates, bottom facies, and sub-bottom stratigraphy, northern Outer Banks, NC.

Geological Society of America Abstracts.

Schupp, C.A., 2005. Shore-oblique bars, nearshore gravel outcrops, and their correlation to shoreline change. Master's Thesis, Virginia Institute of Marine Science, College of William and Mary, Gloucester Point.

Schupp, C.A., McNinch, J.E., List, J.H. and Farris, A.S., 2002. Relationship of hotspots to the distribution of surficial surf-zone sediments along the Outer Banks of North Carolina, Eos Transactions, American Geophysical Union.

Schwab, W.C., Thieler, E.R., Allen, J.R., Foster, D.S., Swift, B.A. and Denny, J.F., 2000. Influence of inner-continental shelf geologic framework on the evolution and behavior of the barrier-island system between Fire Island Inlet and Shinnecock Inlet, Long Island, New York. J. Coast. Res., 16(2): 408-422.

Shackleton, N.J., 1987. Oxygen isotopes, ice volume and sea level. Quaternary Science Reviews, 6: 183-190.

Shideler, G.L., Swift, D.J.P., Johnson, G.H. and Holliday, B.W., 1972. Late Quaternary Stratigraphy of the inner Virginia continental shelf: a proposed standard section. Geological Society of America Bulletin, 83: 1787-1804.

Snedden, J.W. and Dalrymple, R.W., 1999. Modern shelf sand ridges: from historical perspective to a unified hydrodynamic and evolutionary model. In: K.M. Bergman and J.W. Snedden (Editors), Isolated Shallow Marine Sand Bodies: Sequence Stratigraphic Analysis and Sedimentologic Interpretation. SEPM (Society for Sedimentary Geology), Tulsa, Oklahoma.

Swift, D.J.P., 1975. Barrier-island genesis: evidence from the central Atlantic shelf, eastern U.S.A. Sedimentary Geology, 14: 1-43.

Swift, D.J.P., 1976. Coastal sedimentation. In: D.J. Stanley and D.J.P. Swift (Editors), Marine Sediment Transport and Environmental Management. John Wiley and Sons, New York, pp. 255-309.

Swift, D.J.P., Holliday, B., Avignone, N. and Shideler, G., 1972. Anatomy of a shore face ride system, False Cape, Virginia. Mar. Geol., 12: 59-84.

Thieler, E.R., Pilkey, O.H., Jr., Cleary, W.J. and Schwab, W.C., 2001. Modern sedimentation on the shoreface and inner continental shelf at Wrightsville Beach, North Carolina, USA. J. Sediment. Res., 71(6): 958-970.

Trembanis, A.C., Wright, L.D., Friedrichs, C.T., Green, M.O. and Hume, T., 2004. The effects of spatially complex inner shelf roughness on boundary layer turbulence and current and wave friction: Tairua embayment, New Zealand. Cont. Shelf Res., 24: $1549-1571$. 
USACE, 2005, United States Army Corps of Engineers Coastal Hydraulics Laboratory Website, http://www.frf.usace.army.mil/frf.shtml

Valiela, I., Costa, J., Foreman, K., Teal, J.M., Howes, B. and Aubrey, D., 1990. Transport of water-borne nutrients from watersheds and their effects on coastal waters. Biogeochemistry, 10: 177-198.

van de Meene, J.W.H. and van Rijn, L.C., 2000. The shoreface-connected ridges along the central Dutch coast -- part 1: field observations. Cont. Shelf Res., 20: 22952323.

Wright, L.D. and Short, A.D., 1984. Morphodynamic variability of surf zones and beaches: a synthesis. Mar. Geol., 56: 93-118.

Zar, J.H., 1999. Biostatistical Analysis. Prentice Hall, Upper Saddle River, New Jersey, $663 \mathrm{pp}$. 
VITA

\section{ALACIA GRACE BROWDER}

Born at Mountain Home A.F.B., Idaho, 10 January 2005. Graduated from Niceville High School, Niceville, Florida in 1991. Earned B.A. in French from Washington and Lee University, Lexington, Virginia in 1995. Earned B.S. in Biology from The Univeristy of Georgia, Athens, Georgia in 2000. Entered masters program in College of William and Mary, School of Marine Science in 2002. 